Prepared in cooperation with the U.S. Army Corps of Engineers, Vicksburg District

\title{
Nutrient and Sediment Concentrations and Loads in the Steele Bayou Basin, Northwestern Mississippi, 2010-14
}

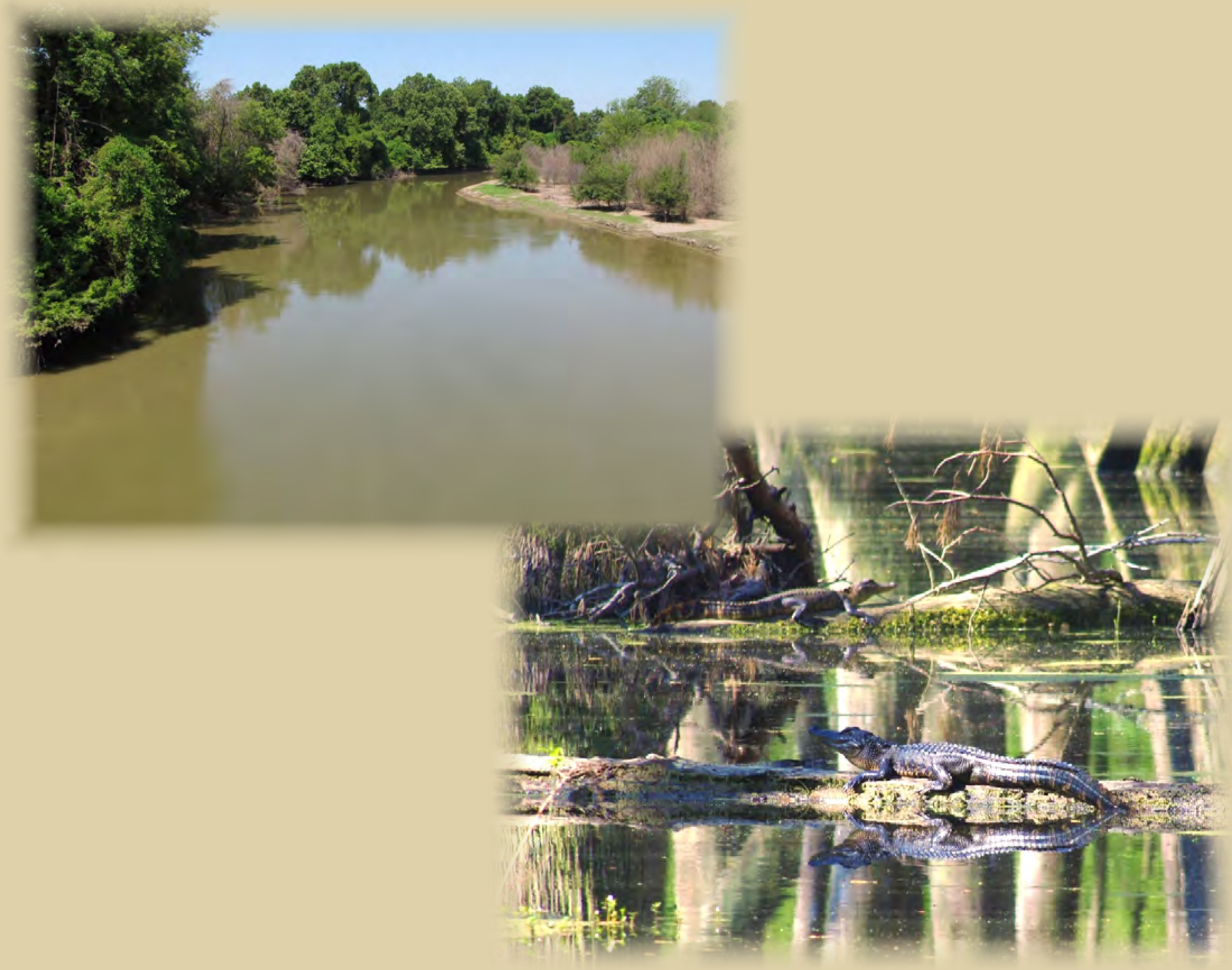

Scientific Investigations Report 2017-5035 
Cover. Steele Bayou near Glen Allen. Photograph by Shane Stocks, U.S. Geological Survey. Alligators in back swamps. Photograph by Shane Stocks, U.S. Geological Survey. 


\section{Nutrient and Sediment Concentrations and Loads in the Steele Bayou Basin, Northwestern Mississippi, 2010-14}

By Matthew B. Hicks, Jennifer C. Murphy, and Shane J. Stocks

Prepared in cooperation with the U.S. Army Corps of Engineers, Vicksburg District

Scientific Investigations Report 2017-5035 


\title{
U.S. Department of the Interior \\ RYAN K. ZINKE, Secretary
}

\section{U.S. Geological Survey William H. Werkheiser, Acting Director}

\author{
U.S. Geological Survey, Reston, Virginia: 2017
}

For more information on the USGS - the Federal source for science about the Earth, its natural and living resources, natural hazards, and the environment—visit http://www.usgs.gov or call 1-888-ASK-USGS.

For an overview of USGS information products, including maps, imagery, and publications, visit http://store.usgs.gov.

Any use of trade, firm, or product names is for descriptive purposes only and does not imply endorsement by the U.S. Government.

Although this information product, for the most part, is in the public domain, it also may contain copyrighted materials as noted in the text. Permission to reproduce copyrighted items must be secured from the copyright owner.

Suggested citation:

Hicks, M.B., Murphy, J.C., and Stocks, S.J., 2017, Nutrient and sediment concentrations and loads in the Steele Bayou Basin, northwestern Mississippi, 2010-14: U.S. Geological Survey Scientific Investigations Report 2017-5035, 32 p., https://doi.org/10.3133/sir20175035.

ISSN 2328-0328 (online) 


\section{Contents}

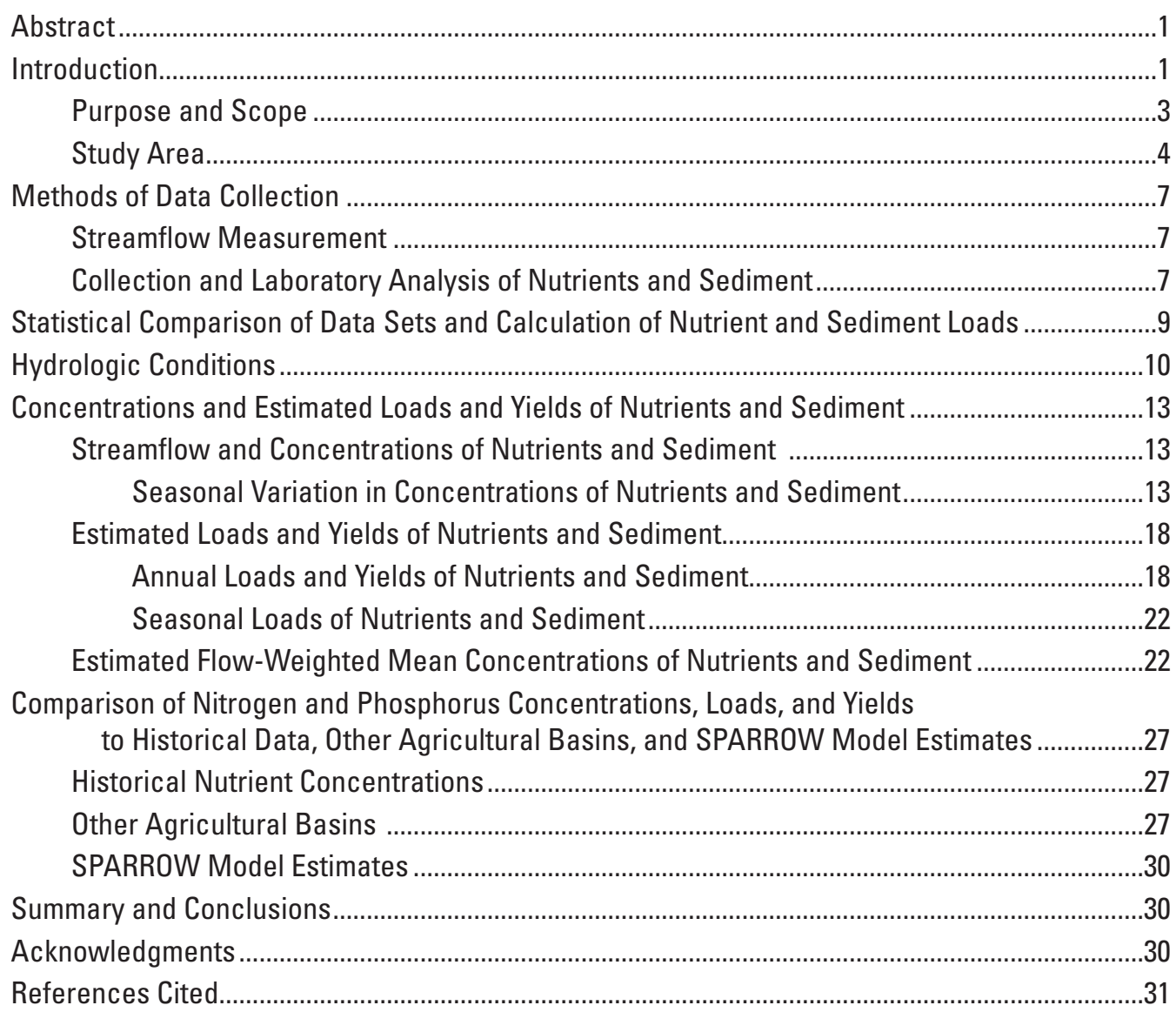

\section{Figures}

1. Map showing location of the study area, associated surface-water features, and surface-water monitoring stations in the Steele Bayou Basin, Mississippi, 2010-14.

2. Map showing land cover in the Steele Bayou Basin, Mississippi, 2011 ..........................5

3. Hydrographs showing mean daily streamflow and the times and flows for which water-quality samples were collected at the Steele Bayou near Glen Allan, MS, and Steele Bayou at Grace Road at Hopedale, MS, surface-water monitoring stations in the Steele Bayou Basin, Mississippi, water years 2011-14.

4. Graphs showing annual and monthly precipitation totals at the Rolling Fork National Oceanic and Atmospheric Administration weather station, calendar years 2010-14

5. Graphs showing mean monthly streamflow for water years 2011-14 at the Steele Bayou near Glen Allan, MS, and Steele Bayou at Grace Road at Hopedale, MS, surface-water monitoring stations. 
6. Box plots showing seasonal distributions of total nitrogen concentrations in water-quality samples collected during baseflow and runoff conditions at the Steele Bayou near Glen Allan, MS, and Steele Bayou at Grace Road at Hopedale, MS, water-quality stations in the Steele Bayou Basin, Mississippi, water years 2011-14

7. Box plots showing seasonal distributions of nitrate plus nitrite concentrations in water-quality samples collected during baseflow and runoff conditions at the Steele Bayou near Glen Allan, MS, and Steele Bayou at Grace Road at Hopedale, MS, water-quality stations in the Steele Bayou Basin, Mississippi, water years 2011-14

8. Box plots showing seasonal distributions of total phosphorus concentrations in water-quality samples collected during baseflow and runoff conditions at the Steele Bayou near Glen Allan, MS, and Steele Bayou at Grace Road at Hopedale, MS, water-quality stations in the Steele Bayou Basin, Mississippi, water years 2011-14.

9. Box plots showing seasonal distributions of orthophosphate concentrations in water-quality samples collected during baseflow and runoff conditions at the Steele Bayou near Glen Allan, MS, and Steele Bayou at Grace Road at Hopedale, MS, water-quality stations in the Steele Bayou Basin, Mississippi, water years 2011-14

10. Box plots showing seasonal distributions of suspended sediment concentrations in water-quality samples collected during baseflow and runoff conditions at the Steele Bayou near Glen Allan, MS, and Steele Bayou at Grace Road at Hopedale, MS, water-quality stations in the Steele Bayou Basin, Mississippi, water years 2011-14

11. Box plots showing seasonal ratios of nitrate plus nitrite to total nitrogen at the Steele Bayou near Glen Allan, MS, and Steele Bayou at Grace Road at Hopedale, MS, water-quality stations in the Steele Bayou Basin, Mississippi, water years 2011-14

12. Box plots showing seasonal ratios of orthophosphate to total phosphorus at the Steele Bayou near Glen Allan, MS, and Steele Bayou at Grace Road at Hopedale, MS, water-quality stations in the Steele Bayou Basin, Mississippi, water years 2011-14.

\section{Tables}

1. Streamflow-gaging station information and average annual streamflow for the water-quality stations sampled in the Steele Bayou Basin, Mississippi, 2010-14

2. Summary statistics of total nitrogen, nitrite plus nitrate, total phosphorus, orthophosphate and suspended sediment concentrations in water-quality samples collected during baseflow and runoff conditions at water-quality stations in the Steele Bayou Basin, Mississippi, October 2010 through September 2014 .

3. Regression models used for estimating total nitrogen, nitrite plus nitrate, total phosphorus, orthophosphate and suspended sediment concentration loads at water-quality stations sampled in the Steele Bayou Basin, Mississippi, October 2010 to September 2014.

4. Estimated annual total nitrogen loads and yields in the Steele Bayou Basin, Mississippi, October 2010 through September 2014. 
5. Estimated annual nitrite plus nitrate loads and yields in the Steele Bayou Basin, Mississippi, October 2010 through September 2014.

6. Estimated annual total phosphorus loads and yields in the Steele Bayou Basin, Mississippi, October 2010 through September 2014...

7. Estimated annual orthophosphate loads and yields in the Steele Bayou Basin, Mississippi, October 2010 through September 2014..

8. Estimated suspended sediment loads and yields in the Steele Bayou Basin, Mississippi, October 2010 through September 2014..

9. Estimates of seasonal total nitrogen loads in the Steele Bayou Basin, Mississippi, October 2010 through September 2014

10. Estimates of seasonal nitrite plus nitrate loads in the Steele Bayou Basin, Mississippi, October 2010 through September 2014

11. Estimates of seasonal total phosphorus loads in the Steele Bayou Basin, Mississippi, October 2010 through September 2014

12. Estimates of seasonal orthophosphate loads in the Steele Bayou Basin, Mississippi, October 2010 through September 2014.

13. Estimates of seasonal suspended sediment loads in the Steele Bayou Basin, Mississippi, October 2010 through September 2014.

14. Estimated annual total nitrogen loads, average annual streamflows, and flow-weighted mean total nitrogen concentrations at water-quality stations in the Steele Bayou Basin, Mississippi, October 2010 through September 2014

15. Estimated annual total phosphorus loads, average annual streamflows, and flow-weighted mean total phosphorus concentrations at water-quality stations in the Steele Bayou Basin, Mississippi, October 2010 through September 2014

16. Estimated annual suspended sediment loads, average annual streamflows, and flow-weighted mean sediment concentrations at water-quality stations in the Steele Bayou Basin, Mississippi, October 2010 through September 2014.

17. Estimated annual total nitrogen, nitrite plus nitrate, total phosphorus and suspended sediment loads, from other published agricultural dominated basins and from water-quality stations in the Steele Bayou Basin, Mississippi, October 2010 through September 2014 


\section{Conversion Factors}

\begin{tabular}{|c|c|c|}
\hline Multiply & By & To obtain \\
\hline \multicolumn{3}{|c|}{ Length } \\
\hline inch & $2.54 \times 10^{4}$ & micrometer $(\mu \mathrm{m})$ \\
\hline inch (in.) & 25.4 & millimeter $(\mathrm{mm})$ \\
\hline foot $(\mathrm{ft})$ & 0.3048 & meter $(\mathrm{m})$ \\
\hline mile (mi) & 1.609 & kilometer $(\mathrm{km})$ \\
\hline \multicolumn{3}{|c|}{ Area } \\
\hline acre & 0.004047 & square kilometer $\left(\mathrm{km}^{2}\right)$ \\
\hline square mile $\left(\mathrm{mi}^{2}\right)$ & 2.590 & square kilometer $\left(\mathrm{km}^{2}\right)$ \\
\hline \multicolumn{3}{|c|}{ Volume } \\
\hline gallon (gal) & 3.785 & liter $(\mathrm{L})$ \\
\hline cubic foot $\left(\mathrm{ft}^{3}\right)$ & 0.02832 & cubic meter $\left(\mathrm{m}^{3}\right)$ \\
\hline \multicolumn{3}{|c|}{ Flow rate } \\
\hline cubic foot per second $\left(\mathrm{ft}^{3} / \mathrm{s}\right)$ & 0.02832 & cubic meter per second $\left(\mathrm{m}^{3} / \mathrm{s}\right)$ \\
\hline $\begin{array}{l}\text { cubic foot per second per square } \\
\text { mile }\left[\left(\mathrm{ft}^{3} / \mathrm{s}\right) / \mathrm{mi}^{2}\right]\end{array}$ & 0.01093 & $\begin{array}{l}\text { cubic meter per second per square } \\
\text { kilometer }\left[\left(\mathrm{m}^{3} / \mathrm{s}\right) / \mathrm{km}^{2}\right]\end{array}$ \\
\hline \multicolumn{3}{|c|}{ Precipitation } \\
\hline inch per year (in/yr) & 25.4 & millimeter per year $(\mathrm{mm} / \mathrm{yr})$ \\
\hline \multicolumn{3}{|c|}{ Mass } \\
\hline pound, avoirdupois (lb) & 0.4536 & kilogram $(\mathrm{kg})$ \\
\hline ton, short $(2,000 \mathrm{lb})$ & 0.9072 & metric ton $(\mathrm{t})$ \\
\hline \multicolumn{3}{|c|}{ Yield } \\
\hline $\begin{array}{l}\text { on per day per square mile } \\
{\left[(\text { ton } / \mathrm{d}) / \mathrm{mi}^{2}\right]}\end{array}$ & 0.3503 & $\begin{array}{l}\text { metric ton per day per square } \\
\text { kilometer }\left[(\mathrm{t} / \mathrm{d}) / \mathrm{km}^{2}\right]\end{array}$ \\
\hline ton per square mile (ton $/ \mathrm{mi}^{2}$ ) & 0.3503 & $\begin{array}{l}\text { metric ton per square kilometer } \\
\left(\mathrm{t} / \mathrm{km}^{2}\right)\end{array}$ \\
\hline \multicolumn{3}{|c|}{ Load } \\
\hline ton per year (ton/yr) & 0.9072 & megagram per year $(\mathrm{Mg} / \mathrm{yr})$ \\
\hline ton per year (ton/yr) & 0.9072 & metric ton per year $(\mathrm{t} / \mathrm{yr})$ \\
\hline \multicolumn{3}{|c|}{ Slope } \\
\hline foot per mile ( $\mathrm{ft} / \mathrm{mi})$ & 0.1894 & meter per kilometer $(\mathrm{m} / \mathrm{km})$ \\
\hline
\end{tabular}




\section{Datum}

Horizontal coordinate information is referenced to the North American Datum of 1983 (NAD 83).

\section{Supplemental Information}

Concentrations of chemical constituents in water are given in milligrams per liter (mg/L).

A water year is defined as the 12-month period 0 ctober 1 , for any given year through September 30 , of the following year.

\section{Abbreviations}

$\begin{array}{ll}\text { AIC } & \text { Akaike Information Criterion } \\ \text { AICc } & \text { corrected Akaike Information Criterion } \\ \text { AMLE } & \text { adjusted maximum likelihood estimation } \\ \text { EPA } & \text { U.S. Environmental Protection Agency } \\ \text { EQIP } & \text { Environmental Quality Incentives Program } \\ \text { FARM } & \text { Farmers Advocating Resource Management } \\ \text { FWM } & \text { flow-weighted mean } \\ \text { GIS } & \text { geographic information system } \\ \text { HFV } & \text { high-frequency variation } \\ \text { MDEO } & \text { Mississippi Department of Environmental Quality } \\ \text { NWOL } & \text { National Water Quality Laboratory } \\ \text { POR } & \text { period of record } \\ \text { SPARROW } & \underline{\text { Spatially-Referenced Regression on Watershed }} \\ \text { TMDL } & \text { total maximum daily load } \\ \text { USACE } & \text { U.S. Army Corps of Engineers } \\ \text { USDA } & \text { U.S. Department of Agriculture } \\ \text { USGS } & \text { U.S. Geological Survey }\end{array}$





\title{
Nutrient and Sediment Concentrations and Loads in the Steele Bayou Basin, Northwestern Mississippi, 2010-14
}

\author{
By Matthew B. Hicks, Jennifer C. Murphy, and Shane J. Stocks
}

\section{Abstract}

The U.S. Geological Survey, in cooperation with the U.S. Army Corps of Engineers-Vicksburg District, monitored streamflow, water quality, and sediment at two stations on the Steele Bayou in northwestern Mississippi from October 2010 through September 2014 to characterize nutrient and sediment concentrations and loads in areas where substantial implementation of conservation efforts have been implemented. The motivation for this effort was to quantify improvements, or lack thereof, in water quality in the Steele Bayou watershed as a result of implementing large- and small-scale best-management practices aimed at reducing nutrient and sediment concentrations and loads. The results of this study document the hydrologic, water-quality, and sedimentation status of these basins following over two decades of ongoing implementation of conservation practices.

Results from this study indicate the two Steele Bayou stations have comparable loads and yields of total nitrogen, phosphorus, and suspended sediment when compared to other agricultural basins in the southeastern and central United States. However, nitrate plus nitrite yields from basins in the Mississippi River alluvial plain, including the Steele Bayou Basin, are generally lower than other agricultural basins in the southeastern and central United States.

Seasonal variation in nutrient and sediment loads was observed at both stations and for most constituents. About 50 percent of the total annual nutrient and sediment load was observed during the spring (February through May) and between 25 and 50 percent was observed during late fall and winter (October through January). These seasonal patterns probably reflect a combination of seasonal patterns in precipitation, runoff, streamflow, and in the timing of fertilizer application.

Median concentrations of total nitrogen, nitrate plus nitrite, total phosphorus, orthophosphate, and suspended sediment were slightly higher at the upstream station, Steele Bayou near Glen Allan, than at the downstream station, Steele Bayou at Grace Road at Hopedale, MS, although the differences typically were not statistically significant. Mean annual loads of nitrate plus nitrite and suspended sediment were also larger at the upstream station, although the annual loads at both stations were generally within the 95 -percent confidence intervals of each other.

\section{Introduction}

Nutrients and sediments occur and are transported naturally in aquatic systems. Human activities often disrupt the natural transport processes, however, which may lead to declines in water quality, such as eutrophication and algal blooms or excess sediment transport and declines in habitat quality, ultimately resulting in shifts in the biological community structure (Wood and Armitage, 1997; Herbonne and Vondracek, 2001). Excessive nutrients and sediments in water and the possible negative effects on the health of aquatic systems are an important concern for environmental resources managers. Efforts to reduce nutrients and sediments involve addressing some challenging questions:

- When does a naturally occurring substance, such as nutrients or sediment, become a pollutant?

- What amount (concentration or mass) of nutrients and sediment is sustainable and protective?

- What are realistically achievable reductions of nutrients and sediment, given the necessity to balance environmental protection with economic productivity?

Addressing these types of questions often requires

(1) monitoring streamflow, water quality, and sediment with the goal of comparing results both before and after nutrient and sediment reduction efforts; (2) a scientific understanding of the transport processes occurring within a watershed; and (3) cooperation between water users, wastewater dischargers, and resource managers.

Empirical data and modeling results suggest the Yazoo River Basin, which is a large and primarily agricultural basin in northern and western Mississippi (fig. 1), is a source of nutrient loading to the Gulf of Mexico, indicating this region is a contributor to the hypoxic zone located along the inner continental shelf in the Gulf (Alexander and others, 2008; Robertson and others, 2009). In addition, within the past 15 years, several total maximum daily loads (TMDLs) have been developed for impaired waters in this basin, primarily because of sedimentation and nutrient enrichment (Mississippi Department of Environmental Quality, 2003, 2008). Furthermore, the U.S. Environmental Protection Agency's (EPA's) push for numeric nutrient criteria has intensified the desire for nutrient reductions in streams and rivers in the Yazoo River Basin (Mississippi Department of Environmental Quality, 2009). 

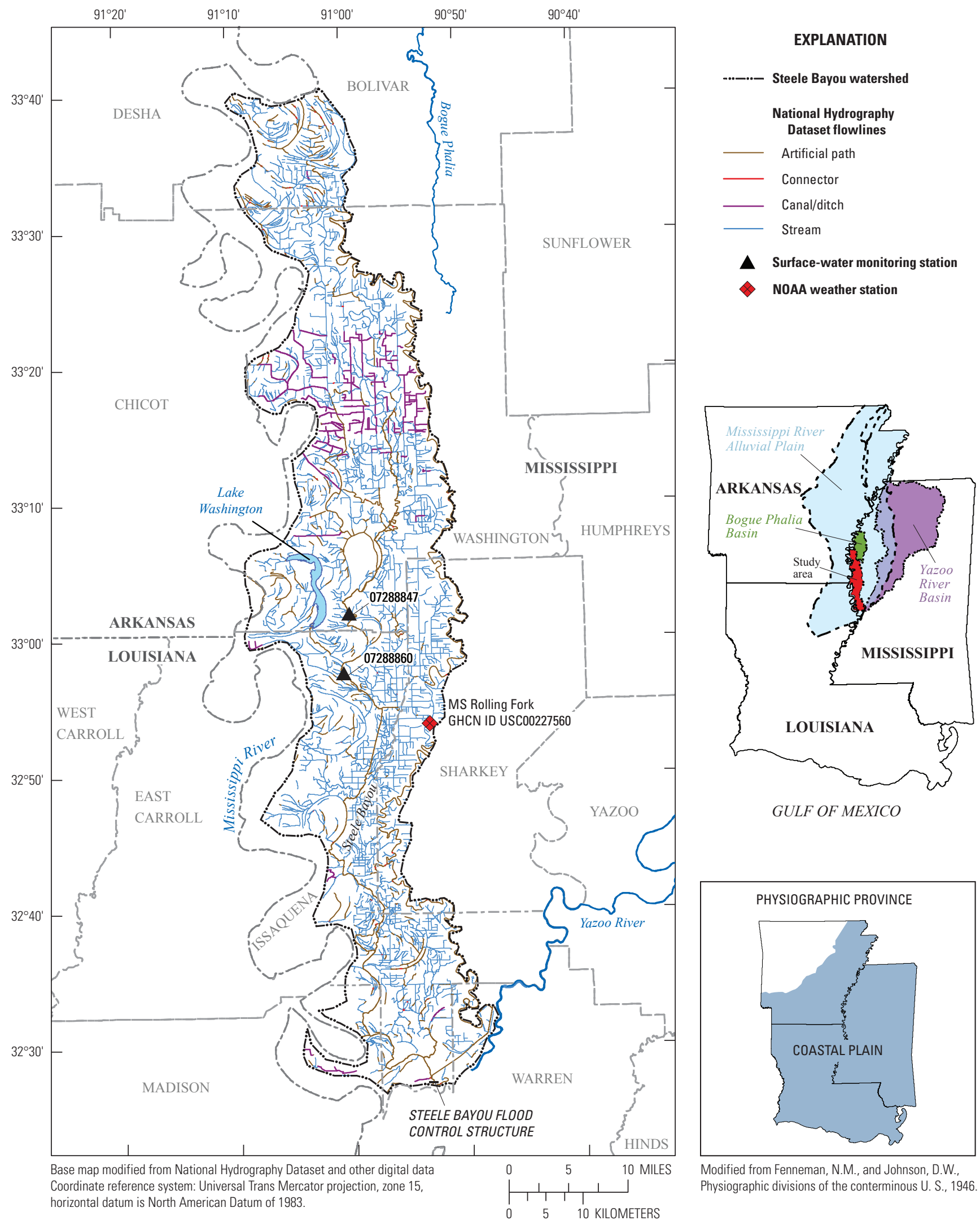

GULF OF MEXICO

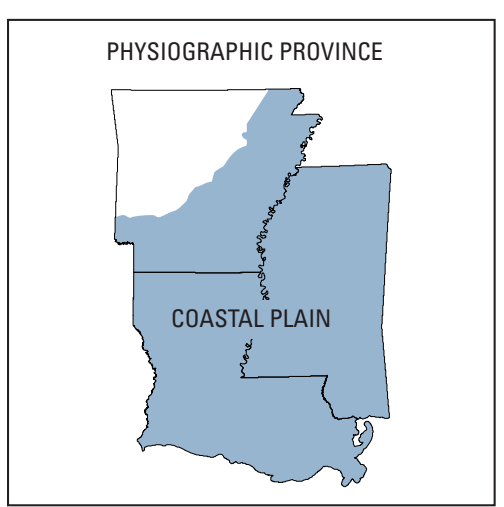

Modified from Fenneman, N.M., and Johnson, D.W., Physiographic divisions of the conterminous U. S., 1946.

Figure 1. Location of the study area, associated surface-water features, and surface-water monitoring stations in the Steele Bayou Basin, Mississippi, 2010-14. 
Steele Bayou, which drains directly into the Yazoo River (fig. 1), is subject to large annual inputs of nutrients and sediment, primarily from nonpoint sources of pollution, such as runoff from agricultural fields. Poor fish-community structure and elevated concentrations of nutrients and sediment documented in several short-term studies suggest poor stream health in the Steele Bayou Basin (Ashby and others, 1991; Slack and Grantham, 1991; Kilgore and others, 2008). The Steele Bayou was listed as impaired on the Mississippi Department of Environmental Quality's (MDEQ) section 303(d) list in 1996, with the causes of impairment attributed to pesticides, organic enrichment and (or) low dissolved oxygen, nutrients, and siltation. In 2003, the MDEQ developed a TMDL for sediment for the Steele Bayou Basin (Mississippi Department of Environmental Quality, 2003) and established a range of acceptable daily yields of sediment (0.59-1.8 metric tons per square kilometer $\left[\mathrm{t} / \mathrm{km}^{2}\right]$ ). In 2008, the MDEQ developed a TMDL for nutrients (total phosphorus and total nitrogen) for large rivers in the Mississippi portion of the Mississippi River alluvial plain, including Steele Bayou, and established concentration endpoints of 0.16 milligram per liter $(\mathrm{mg} / \mathrm{L})$ for total phosphorus and $1.05 \mathrm{mg} / \mathrm{L}$ for total nitrogen (Mississippi Department of Environmental Quality, 2008).

Since the 1990s, numerous efforts by landowners and State and Federal cooperators have been implemented to reduce sediment and nutrient loads in the Steele Bayou Basin. Installation of instream and landscape conservation practices as prescribed in these efforts total more than $\$ 15$ million (Dave Johnson, U.S. Army Corps of Engineers, Vicksburg District, written commun., 2013). The U.S. Army Corps of Engineers (USACE) invested \$9 million in largescale ecosystem restoration and flood-control mitigation projects throughout much of the basin beginning in 1995 and continuing through the end of 2014. The Environmental Quality Incentives Program (EQIP) administered by the U.S. Department of Agriculture (USDA) has funded several million dollars in projects since 1998 (Dave Johnson, U.S. Army Corps of Engineers, Vicksburg District, written commun., 2013). In 2007, the MDEQ, in partnership with Delta Farmers Advocating Resource Management (Delta FARM), spent more than $\$ 500,000$ on small-scale sediment and erosion-control projects using EPA Section 319 funding. Beyond governmentfunded projects, an unknown amount of private funding has been spent by landowners for management practices across this region. Practices and structures targeted for soil and water conservation during this period of time funded by the various sources include land leveling, installation of field pads, drop pipes, slotted board risers, implementation of no-till farming, construction of weirs, channel cleanout, installation of grade-stabilization structures, and installation of conservation buffers.

Given the vast amount of time, resources, and energy invested in improving water quality in the Steele Bayou Basin, observing and documenting improvements in water quality is a top priority. Over the past two decades, some visual and qualitative improvements in water quality and ecosystem health have been observed and (or) documented. In 2004, the EPA Region IV Administrator and officials from the USACE toured portions of the lower Yazoo River Basin by helicopter. During that tour, water clarity of the Steele Bayou was visually observed to be markedly less turbid than other large rivers in the lower Yazoo River Basin (Dave Johnson, U.S. Army Corps of Engineers, Vicksburg District, written commun., 2011). With respect to biological communities, Killgore and others (2008) found that habitat properties and fish community diversity and abundance improved from 1990 to 2000 in the Steele Bayou. Although visual and qualitative documentation of potential improvements in water quality are important, there is a need to quantify potential reductions in nutrients and sediment and determine whether those reductions can be attributed to the conservation practices that have been implemented.

After more than a decade of nutrient and sediment reduction efforts, the U.S. Geological Survey (USGS), in cooperation with the USACE, Vicksburg District, began a study in 2010 to monitor and describe streamflow and water quality in the Steele Bayou. The motivation for this project was to begin to understand and document existing water quality and eventually be able to discern improvements, or the lack thereof, in water quality in the Steele Bayou over time. At this time, the direct effect of conservation practices on water quality cannot be assessed in the Steele Bayou because of the limited data available prior to the implementation of conservation practices in the basin, the relatively short period of monitoring completed for this study, and lack of a similar comparison basin where conservation practices are generally absent. Instead, the water-quality and streamflow characterization presented in this report provides a baseline for addressing future changes in the Steele Bayou and comparable basins.

\section{Purpose and Scope}

This report describes aspects of hydrology, water quality, and sediment transport in the Steele Bayou Basin during a 4-year period following the implementation of extensive conservation practices. Specifically, this report summarizes the streamflow and water-quality and sediment data collected between October 2010 and September 2014 at two USGS surface-water monitoring stations along the Steele Bayou; presents estimates of nutrient and sediment loads; characterizes the annual and seasonal variability of concentrations, loads, and yields of nutrients and sediment; compares differences in water quality and sediment between samples collected during runoff and baseflow; assesses differences in water quality and sediment between the two stations; and lastly, relates estimated annual loads and yields of nutrients and sediment to similar agricultural basins in the Southeast and Central United States, estimates from the Spatially- $\underline{R}$ eferenced $\underline{R}$ egression on Watershed (SPARROW) model, and TMDL endpoints, for context. 


\section{Study Area}

The Yazoo River Basin is the largest basin in Mississippi. The "Delta" is a term used locally to describe the downstream or lower portion of the Yazoo River Basin that is within the Mississippi River alluvial plain of the Coastal Plain physiographic province (fig. 1). The Delta is a low-relief, alluvial valley of the Mississippi River that has slightly undulating topography and an average gulfward slope of about 0.5 foot per mile ( $\mathrm{ft} / \mathrm{mi}$ ). The Steele Bayou Basin, which constitutes the study area for the current investigation, is located on the western edge of the Delta and drains directly into the Yazoo River approximately 13 miles (mi) upstream from where the Yazoo empties into the Mississippi River.

The Steele Bayou Basin was once part of the Mississippi River floodplain and was covered with bottomland hardwoods, marshes, and wetlands (Kleiss and others, 2000). Expansive land clearing and hydrologic modification of this area, coupled with a long growing season and average rainfall of more than 52 inches (in.), resulted in a highly productive agricultural region. Starting in the 1990s, the USACE built extensive levee systems and in-channel flood control structures and channelized many waterways in an effort to control flooding. To control backwater flooding from the Mississippi River, a floodgate was built at the mouth of Steele Bayou. The floodgate is open during normal operation allowing water to flow from the Steele Bayou into the Yazoo River, but is closed during periods of high flow in the Mississippi River to prevent reverse flow into the Yazoo River Basin. During times when the floodgate is closed, backwater flooding can still occur in the lower portion of Steele Bayou because the floodgate acts as a dam, preventing water flowing downstream in the Steele Bayou from exiting.

The Steele Bayou Basin is located in Bolivar, Washington, and Issaquena Counties in western Mississippi and is sparsely populated, having no major metropolitan areas. Urban areas represent about 3 percent of the land use in the Steele Bayou Basin, deciduous and evergreen forest and woody and emergent herbaceous wetlands represent about 17 percent, and agriculture represents about 72 percent (fig. 2). The primary crops farmed include soybeans, cotton, rice, corn, and grain sorghum. Land-use changes and management practices for sediment and nutrient control have been more predominant in the middle and upper portions of the Steele Bayou Basin than in the lower portion.

Streamflow, water quality, and sediment were monitored at two USGS surface-water monitoring stations in the central portion of the Steele Bayou Basin (fig. 1, table 1). The upper station, Steele Bayou near Glen Allan, MS (USGS station 07288847), referred to as "Steele Bayou near Glen Allan" throughout rest of report, is located along a reach that drains 837 square kilometers $\left(\mathrm{km}^{2}\right)$. The lower station, Steele Bayou at Grace Road at Hopedale, MS (USGS station 07288860), referred to as "Steele Bayou at Hopedale" throughout rest of report, is located along a reach that drains $1,031 \mathrm{~km}^{2}$. The two stations are less than 10 river miles apart from each other; however, a tributary draining from Lake Washington, an oxbow lake of the Mississippi River, enters Steels Bayou between the two stations and was considered to be a possible source of nutrients for Steele Bayou.

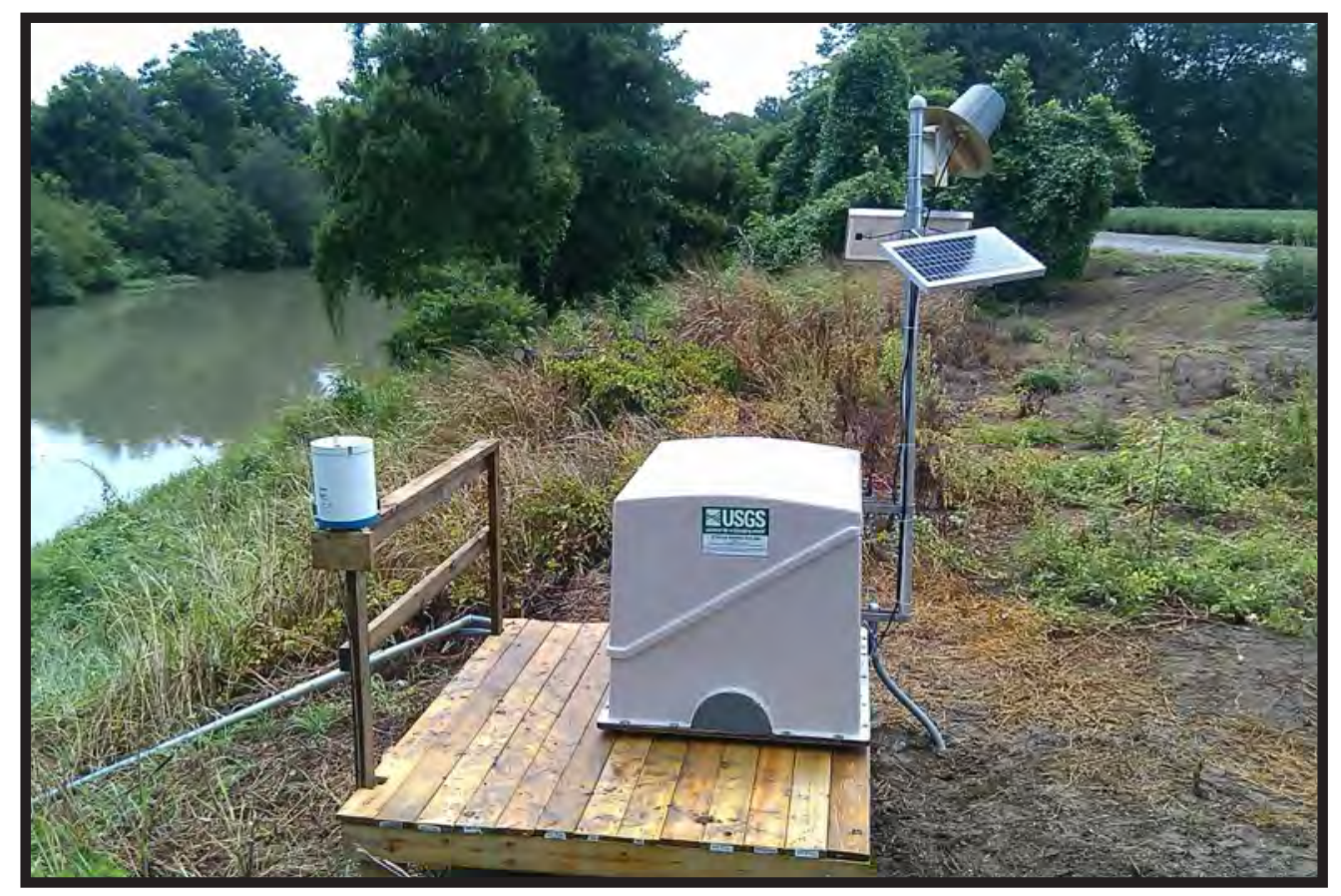




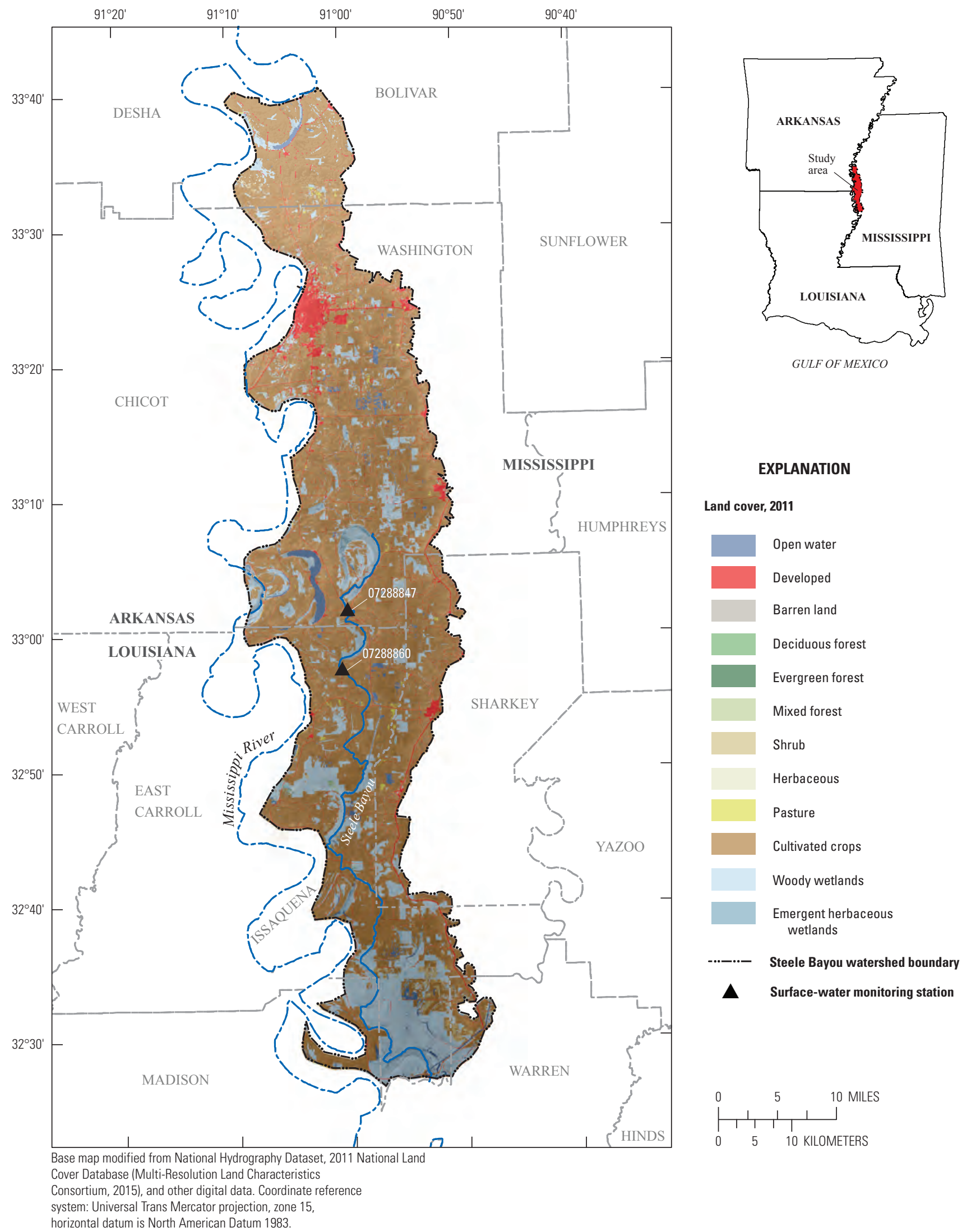

Figure 2. Land cover in the Steele Bayou Basin, Mississippi, 2011. 
Table 1. Streamflow-gaging station information and annual streamflow for the water-quality stations sampled in the Steele Bayou Basin, Mississippi, $2010-14$.

[USGS, U.S. Geological Survey; ddmmss, degrees minutes seconds; km², square kilometer; $\mathrm{ft}^{3} / \mathrm{s}$, cubic foot per second; MS, Mississippi; WY, water year]

\begin{tabular}{|c|c|c|c|c|c|c|c|c|c|}
\hline \multirow{2}{*}{$\begin{array}{l}\text { USGS station } \\
\text { name (number) }\end{array}$} & \multirow{2}{*}{$\begin{array}{l}\text { Abbreviated } \\
\text { station name }\end{array}$} & \multirow{2}{*}{$\begin{array}{l}\text { Latitude } \\
\text { (ddmmss) }\end{array}$} & \multirow{2}{*}{$\begin{array}{l}\text { Longitude } \\
\text { (ddmmss) }\end{array}$} & \multirow{2}{*}{$\begin{array}{l}\text { Drainage } \\
\text { area }\left(\mathrm{km}^{2}\right)\end{array}$} & \multicolumn{4}{|c|}{ Annual mean streamflow $\left(\mathrm{ft}^{3} / \mathrm{s}\right)$} & \multirow{2}{*}{$\begin{array}{c}\begin{array}{c}\text { Mean annua } \\
\text { streamflow } \\
\left(\mathrm{ft}^{3} / \mathrm{s}\right)\end{array} \\
\text { WY 2011-14 }\end{array}$} \\
\hline & & & & & WY 2011 & WY 2012 & WY 2013 & WY 2014 & \\
\hline $\begin{array}{l}\text { Steele Bayou near Glen Allan, } \\
\text { MS (07288847) }\end{array}$ & Steele Bayou near Glen Allan & 330153 & 905953 & 837 & 112 & 331 & 568 & 502 & 378 \\
\hline $\begin{array}{c}\text { Steele Bayou at Grace Road at } \\
\text { Hopedale, MS (07288860) }\end{array}$ & Steele Bayou at Hopedale & 325729 & 910027 & 1,031 & 155 & 407 & 763 & 607 & 483 \\
\hline
\end{tabular}




\section{Methods of Data Collection}

Streamflow was monitored continuously from October 2010 through September 2014 at Steele Bayou near Glen Allan and Steele Bayou at Hopedale. Water samples were collected using a stratified sampling scheme during the study period, because Tortorelli (2008) recommends that surface water-quality and sediment data used to determine concentrations and estimating loads are collected across a range of flow conditions and with similar frequency during all seasons. Water samples were collected at different frequencies during low (baseflow) and high (runoff) flows to better characterize the water quality under such hydrologic conditions and adequately covered the range in streamflow at both stations (fig. 3).

All data in support of this report can be found on the USGS National Water-Information System web portal (U.S. Geological Survey, 2016).

\section{Streamflow Measurement}

Water-surface elevation (stage) was continuously monitored at 15 -minute intervals at both gaging stations using a nonsubmersible pressure sensor attached to a steel pipe near the center of the channel. The pressure sensor measures water pressure, in pounds per square inch, at the bottom of the steel pipe, contrasts this pressure to local atmospheric pressure, and then converts the pressure to water-column height, in feet. Periodically, streamflow was manually measured across a range of flow conditions according to standard USGS guidelines described by Rantz and others (1982). At each station, relations between stage and measured streamflow were developed using data from these manual measurements (Buchanan and Somers, 1969), and these relations were then used to compute continuous streamflow at 15-minute intervals using the monitored stage data (Kennedy, 1983). Daily mean streamflow statistical information was computed using the 15-minute, continuous streamflow data and is available for Steele Bayou near Glen Allan and Steele Bayou at Hopedale for water years 2011-14 (U.S. Geological Survey, 2016).

\section{Collection and Laboratory Analysis of Nutrients and Sediment}

Water samples were collected at both stations for nutrient and suspended sediment analysis. "Routine" water samples were collected manually, usually once a month at low flows, to represent baseflow conditions. All routine samples were collected according to established procedures described in the USGS National Field Manual for the Collection of WaterQuality Data (U.S. Geological Survey, variously dated). Water samples were also collected during periods corresponding to the rising and falling limbs of storm hydrographs to characterize runoff conditions. "Runoff" water samples were collected at the gaging stations by an automatic sampler that was programmed to sample streamflow above a specified stage. When flow was above the specified stage, one sample was collected every 3 hours by filling two 1-liter (L) plastic bottles. Sampling ceased when the flow dropped below the specified stage or once all 24 bottles in the sampler were filled. The total time sampled for each storm ranged from 6 to 12 hours.

Water-quality samples were analyzed at the USGS National Water Quality Laboratory (NWQL) in Denver, Colorado, for total nitrogen, total phosphorus, nitrate plus nitrite, and orthophosphate. Water samples for nutrient analysis were preserved with 4.5-N sulfuric acid and chilled on ice immediately after sample collection. Suspendedsediment samples were analyzed at the USGS sediment laboratory in Baton Rouge, Louisiana, for total suspendedsediment concentrations. All samples were shipped overnight to the analyzing laboratories. During sample collection, quality-control procedures were followed according to the 2006 Quality Assurance Plan for Water-Quality Activities in the USGS Jackson, Mississippi office of the Lower Mississippi-Gulf Water Science Center (R.A. Rebich, U.S. Geological Survey, written commun., 2006). As part of this plan, field replicate samples were collected during routine visits to document data quality as it pertains to sampling technique.

At the USGS NWQL, colorimetry was used to analyze the water samples for nitrogen and phosphorus species (Patton and Truitt, 1992; Fishman, 1993; U.S. Environmental Protection Agency, 1993; Patton and Kryskalla, 2003). At the USGS Baton Rouge sediment laboratory, the suspendedsediment samples were filtered using 1.5-micrometer $(\mu \mathrm{m})$ glass-fiber filters.

Because of the limited amount of censored concentration data - that is, data that are reported less than the detection limit — one half of the detection limit was substituted for censored concentration data in that particular dataset prior to being used in statistical summaries or other analyses of data. Total nitrogen and nitrate plus nitrite were the only constituents with censored data. Four and 5 percent of both total nitrogen and nitrate plus nitrite data from Steele Bayou near Glen Allan and Steele Bayou at Hopedale, respectively, had censored values. 


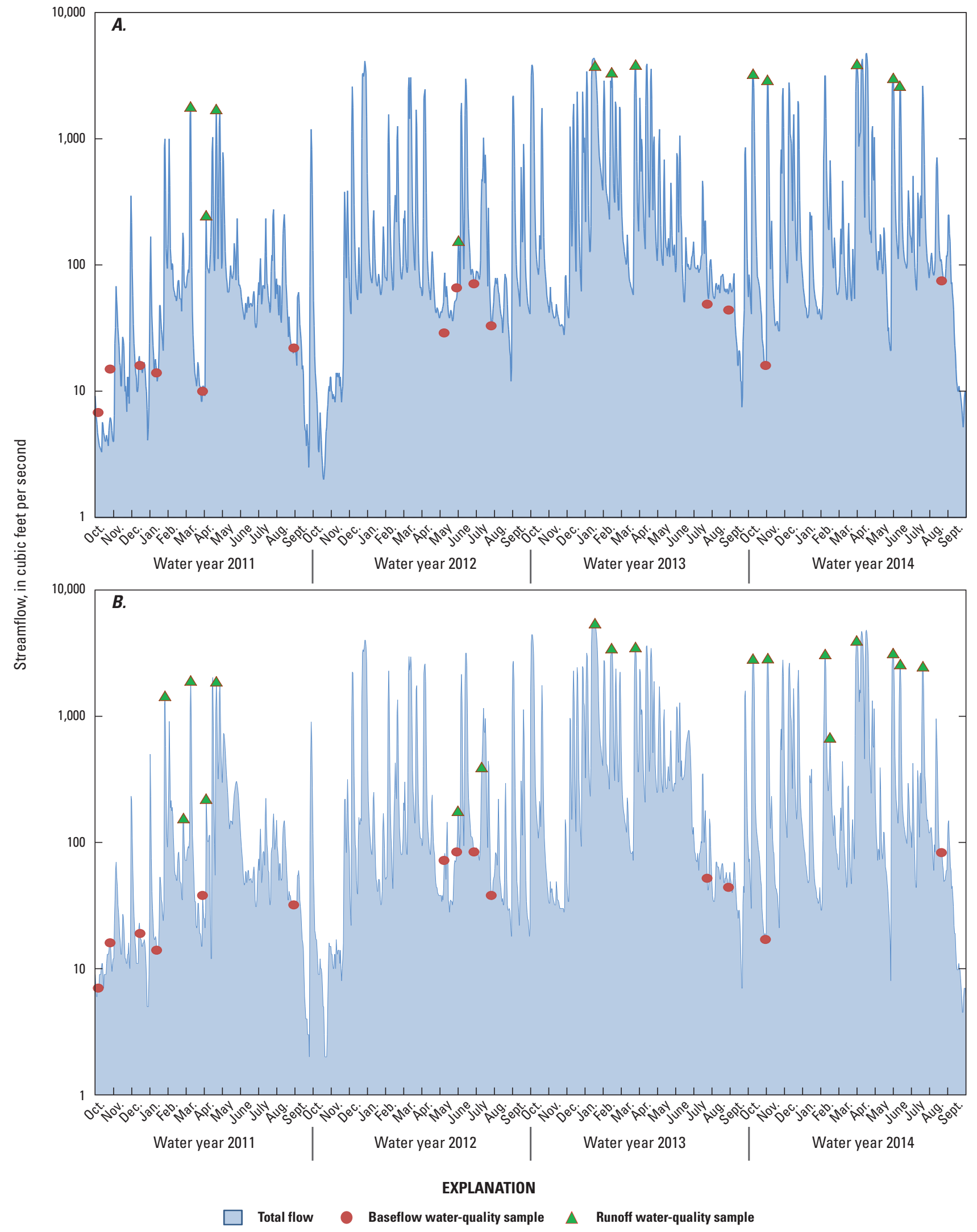

Figure 3. Mean daily streamflow and the times and flows for which water-quality samples were collected at the, $A$, Steele Bayou near Glen Allan, MS, and, $B$, Steele Bayou at Grace Road at Hopedale, MS, surface-water monitoring stations in the Steele Bayou Basin, Mississippi, water years 2011-14. 


\section{Statistical Comparison of Data Sets and Calculation of Nutrient and Sediment Loads}

The Wilcoxon rank-sum test, a nonparametric statistical test, was used to determine the statistical significance of differences between water-quality and sediment samples collected both during baseflow and during runoff, and differences in nutrient and suspended-sediment concentrations between stations. Significant differences in the distribution and central tendency of these datasets were indicated by $\mathrm{p}$-values less than or equal to $(\leq) 0.05$ (Helsel and Hirsch, 1992).

When continuous concentration and streamflow data were available, load was calculated by multiplying concentration by instantaneous streamflow and then integrating the product over a period of time. However, most studies (including this study) monitor streamflow continuously but only collect water-quality data periodically, and thus, estimation is required to determine loads. For this study, multiple linear regression models developed on a daily timestep were used to estimate annual and seasonal loads of nutrients and sediment. For days having more than one water-quality or sediment sample (typically days when samples were collected during a storm), samples were aggregated and a daily mean concentration was reported. If one of the samples was censored, then half the detection limit was substituted, the daily mean concentration was calculated, and the entire day was given a "less than" remark code. Mean concentrations were not flow-weighted, because the use of flow-weighted mean concentrations in place of unweighted concentrations resulted in little difference in the model coefficients and estimates.

Regression models were developed for each station and constituent and the R-package rloadest (Lorenz and others, 2013) was used to calibrate the models. The response variable in all cases was the daily constituent load and the potential explanatory variables included streamflow, season, and time, or some transformation of these variables. Adjusted maximum likelihood estimation (AMLE) was used to estimate the regression model coefficients and apply bias correction factors. AMLE provides an unbiased estimate of load and is especially useful with censored data (Cohn, 2005).

Model development proceeded in three stages. First, a set of predefined models was calibrated, which included some combination of $\log$ (streamflow), $\log$ (streamflow) ${ }^{2}$, time, and seasonal terms (cosine and sine) (see table 3 in Runkel and others, 2004 for a list of predefined models). The model having the lowest corrected Akaike Information Criterion (AICc) (Akaike, 1973; Hurvitch and Tsai, 1989) was initially selected. AICc values are useful for selecting a model from a suite of possible models, and this slightly modified version of the Akaike Information Criterion (AIC) provides better model selection when the calibration dataset contains a small number of samples or the ratio of observations to fitted parameters is large. Second, in the model having the lowest AICc, flow anomaly terms were substituted for $\log$ (streamflow) and $\log (\text { streamflow })^{2}$ terms, and a hysteresis term was added to determine whether the substitution improved model fit. Third, if the anomaly or hysteresis terms were found to be significant, then in order to avoid overfitting the model, the seasonal and temporal terms were removed to test their relative importance.

For some sites, the influence of streamflow on constituent load is better described by long-to-intermediate deviations in streamflow from average flow conditions instead of by daily mean streamflow, which is typically used in most load models (Vecchia, 2003). To test whether this type of information was useful for load estimation at the Steele Bayou stations, 9-, 6-, 3-, and 1-month flow anomaly terms and a corresponding high-frequency variation (HFV) term were determined for each day. Flow anomalies were calculated by taking the mean of the daily flow data for the period of record (POR), subtracting the POR mean from each daily observation, and then calculating the running mean for the previous number of months as indicated for each flow anomaly (for this study, 9-, 6-, 3-, and 1-month). The related HFV was calculated for each day by subtracting the running mean (flow anomaly) from the data. Each flow anomaly was calculated separately and has a related HFV term. This process breaks each daily streamflow value into the POR mean, flow anomaly, and HFV, which, when summed, equal the daily streamflow value. Each pair of flow anomaly and associated HFV terms was tested individually in the regression models and only retained if the terms were statistically significant and their incorporation improved the model.

A hysteresis term was also tested during the second stage of model development. Hysteresis occurs when nutrient and sediment concentrations on the rising limb of a hydrograph differ from those on the falling limb of a hydrograph at the same magnitude of discharge. For some sites, accounting for this fine-scale variability in concentration can provide better estimates of load. To this end, 1-, 3-, and 7-day hysteresis terms were calculated using equation 1 for each day $i$ in the POR

$$
d Q_{k}=\ln Q_{i}-\sum_{j=i-1-k}^{i-1} \ln Q_{j} / k
$$

where

$\begin{aligned} d Q & \text { is the hysteresis term, } \\ \ln & \text { is the natural log, } \\ Q & \text { is daily streamflow, } \\ k & \text { is the number of previous days, } \\ i & \text { is a given day, and } \\ j & \text { is i-1-k. }\end{aligned}$

The 1-day, 3-day and 7-day hysteresis terms were plotted against the model residuals to determine which hysteresis term to test in the model.

During stages two and three of model development, the various candidate models were evaluated and compared using AICc values, $\mathrm{R}^{2}$ values, the range of residual variance, residual plots, and bias statistics. Residuals were calculated for each observation by subtracting the estimated value from the observed value. Residual plots were specifically evaluated for 
normality and homoscedasticity. The bias statistics that were evaluated included load bias $\left(B_{p}\right)$, in percent (equation 2)

$$
B_{p}=100\left(\frac{\sum_{k=1}^{N}(\hat{L}-L)}{\sum_{k=1}^{N} L}\right)
$$

where

$$
\begin{array}{ll}
\hat{L} & \text { is estimated load, } \\
L & \text { is observed load, and } \\
N & \text { is the number of observations in the } \\
& \text { calibration dataset; }
\end{array}
$$

the partial load ratio ( $P L R$, equation 3$)$

$$
P L R=\frac{\sum_{k=1}^{N} \hat{L}}{\sum_{k=1}^{N} L}
$$

and the Nash-Sutcliffe Efficiency Index ( $E$, equation 4; Nash and Sutcliffe, 1970)

$$
E=1-\frac{\sum_{k=1}^{N}(L-\hat{L})^{2}}{\sum_{k=1}^{N}(L-\bar{L})^{2}}
$$

where

$\bar{L} \quad$ is the mean of the observed loads.

The goal of the model development was to select a model having the fewest parameters (most parsimonious), best residual plots, a load bias $\left(B_{p}\right)$ less than 25 percent, a $P L R$ between 0.5 and 2, and an $E$ between 0 and 1 (Runkel and others, 2004). Because no-flow data were collected prior to the start of water-quality and sediment data collection, the calculation of the flow anomalies led to a truncation of the water-quality and sediment calibration dataset. Because of this consequence, the model selection process also aimed to incorporate as much of the water-quality and sediment record as possible. Therefore, as a means of retaining and using as much data as possible, at times if a model with a 9-month flow anomaly had a lower AICc and small residual variance, a model without a flow anomaly (or a shorter flow anomaly) may have been selected if the model diagnostics were comparable.

Given the considerations and evaluations just described, a final model was selected from the iterations in stage three. The selected models were used to estimate seasonal and annual loads and yields. For site-parameter combinations that used a 3-month flow anomaly or hysteresis term, the estimated daily mean flux from the model (in metric tons per day) was multiplied by the number of days in a given year to estimate the annual load. Seasonal loads were estimated the same way, by multiplying the estimated mean load by the total number of days in the seasonal period, if a hysteresis term was used but were not estimated if an anomaly term was used. Seasonal loads were calculated for spring, summer, and fall.
The spring season included the months of February through May, the summer season included the months of June through September, and the fall season included the months of October through January.

\section{Hydrologic Conditions}

Streamflow in the Steele Bayou varied considerably during water years 2011-14 (fig. 3). The mean annual streamflow at the Steele Bayou near Glen Allan and Steele Bayou at Hopedale stations was 378 and 483 cubic feet per second $\left(\mathrm{ft}^{3} / \mathrm{s}\right)$, respectively (table 1$)$. Annual mean streamflow was highest in water year 2013 at both stations, slightly less in water years 2012 and 2014, and substantially less in water year 2011 (table 1). There are no long-term data for historical streamflow at either surface-water monitoring station for comparison; however, annual rainfall totals since 1990 indicate 2010 had the lowest annual rainfall for this 25-year period, well below the 25 -year average (fig. $4 A$ ). Annual rainfall amounts for 2011-14 were slightly below the 25-year average of 53 inches per year (in/yr) (National Oceanic and Atmospheric Administration, 1990-2014). Collectively, the rainfall and streamflow data suggest that 2010 rainfall runoff, streamflow, and associated nutrient and sediment loads may be substantially less than average for this region.

For water years 2011-14, mean monthly streamflow for the two streamflow-gaging stations was generally higher from December through April than during other months (fig. 5). The highest monthly mean streamflows for 2011 and 2014 occurred in April, yet in 2012 and 2013, the highest monthly mean streamflow occurred in December and January, respectively. Typically, low-flow conditions occurred from late summer to fall (August-November), with the exception of a few wet months during this time in 2013 and 2014. As with streamflow, average monthly precipitation was generally highest from December through April and lowest from August through October (fig. $4 B$ ). The percentage of total average annual precipitation that occurred during the growing season (April-October) was typically around 50 percent each year. Specifically, during calendar years 2011-14, approximately 60 percent, 55 percent, 47 percent, and 64 percent of the precipitation occurred during the growing season, respectively. Maximum mean daily streamflow during the study period (fig. 3A, B) occurred in April 2014 at Steele Bayou near Glen Allan $\left(4,770 \mathrm{ft}^{3} / \mathrm{s}\right)$ and in January 2013 at Steele Bayou at Hopedale $\left(5,780 \mathrm{ft}^{3} / \mathrm{s}\right)$. Minimum mean daily streamflow during the study period occurred in October 2011 at both Steele Bayou near Glen Allan $\left(2.0 \mathrm{ft}^{3} / \mathrm{s}\right)$ and Steele Bayou at Hopedale $\left(1.5 \mathrm{ft}^{3} / \mathrm{s}\right)$. 


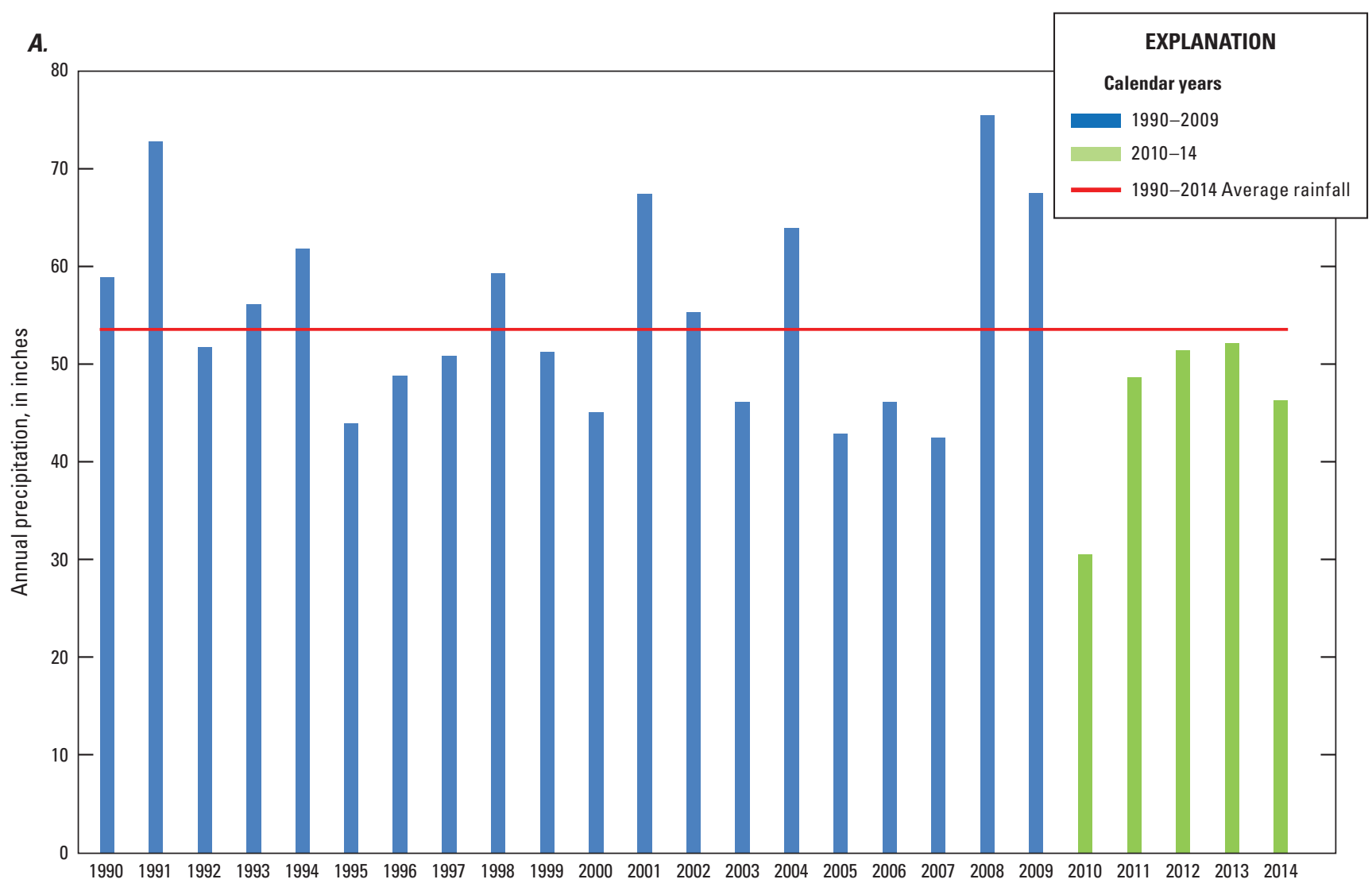

B.

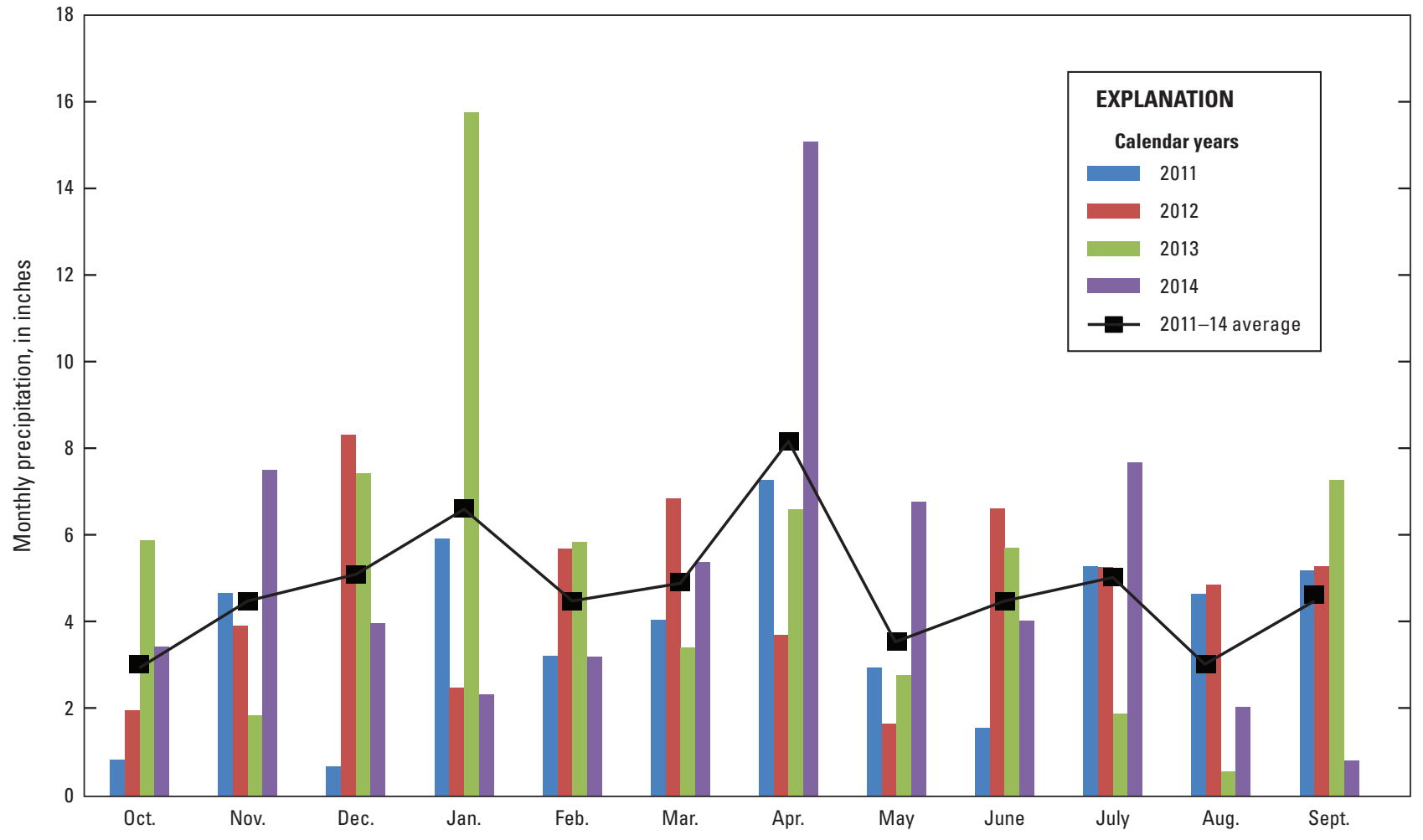

Figure 4. $A$, annual and, $B$, monthly precipitation totals at the Rolling Fork National Oceanic and Atmospheric Administration weather station, calendar years 2010-14. 
A.

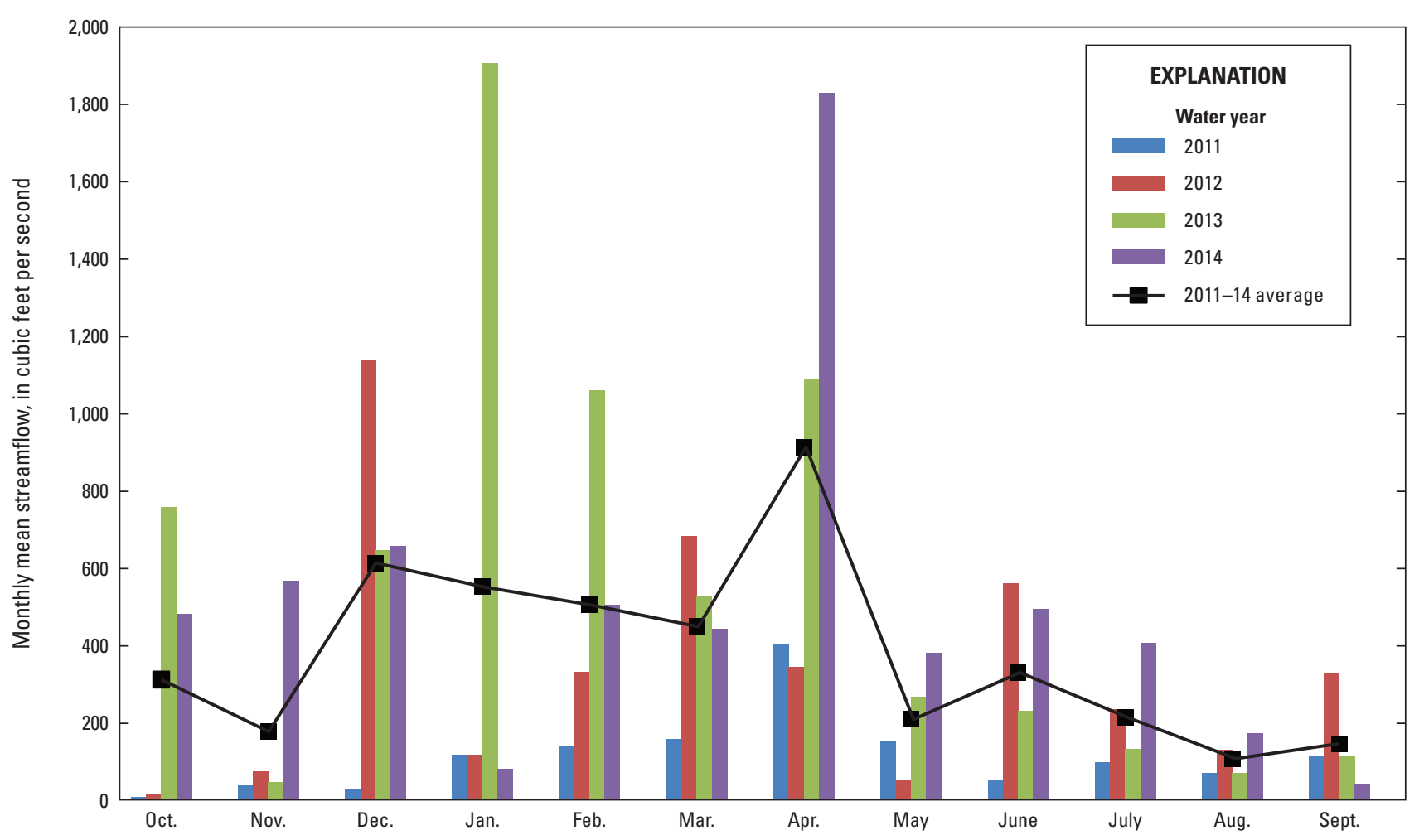

B.

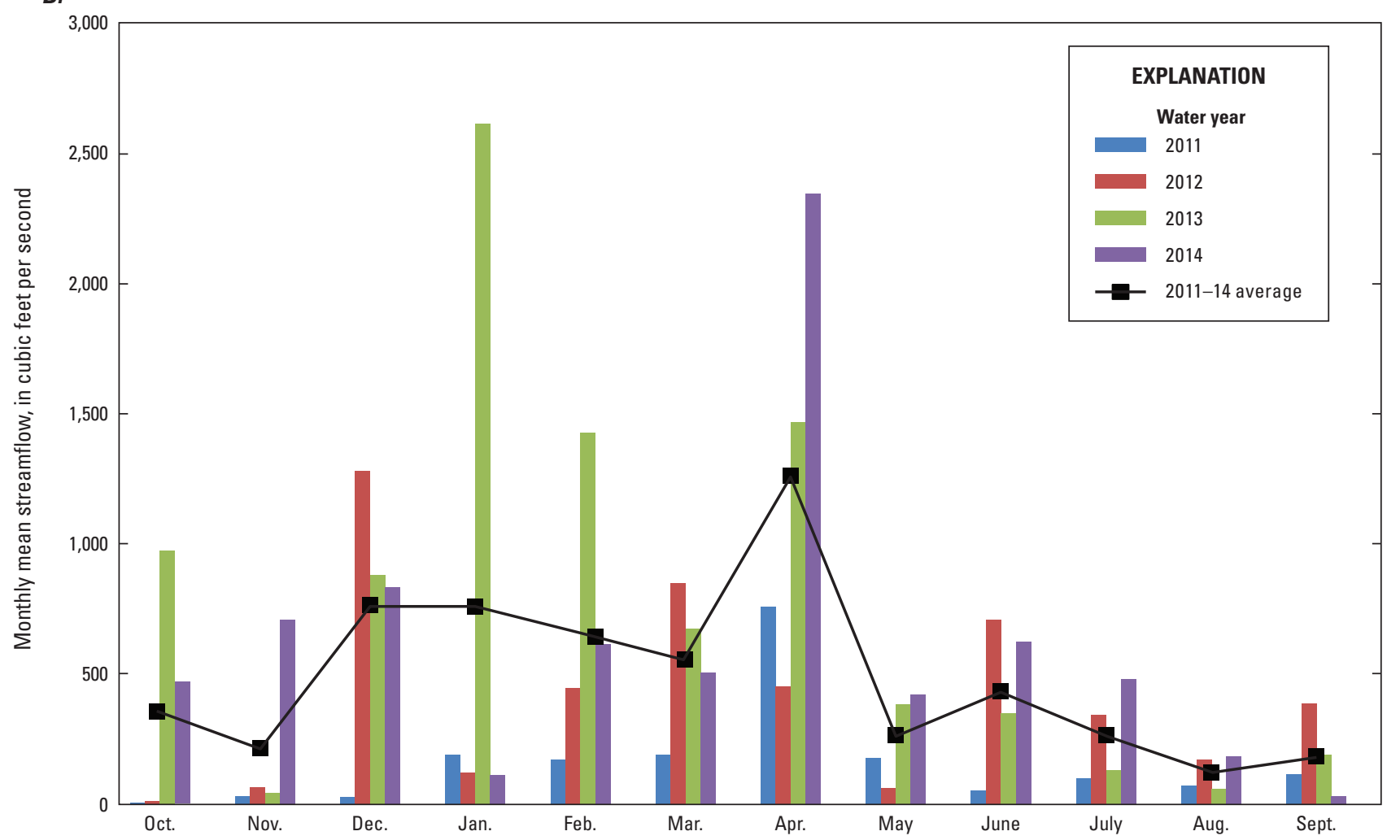

Figure 5. Mean monthly streamflow for water years 2011-14 at the, $A$, Steele Bayou near Glen Allan, MS, and, $B$, Steele Bayou at Grace Road at Hopedale, MS, surface-water monitoring stations. 


\section{Concentrations and Estimated Loads and Yields of Nutrients and Sediment}

Concentrations, loads, and yields of total nitrogen, nitrate plus nitrite, total phosphorus, orthophosphate, and suspended sediment are described for Steele Bayou near Glen Allan and Steele Bayou at Hopedale for water years 2011-14. All annual and seasonal loads and yields are based on mean daily loads estimated using the R-package rloadest (Lorenz and others, 2013).

\section{Streamflow and Concentrations of Nutrients and Sediment}

Concentration data from water-quality and sediment samples collected for water years 2011-14 were grouped on the basis of flow conditions at the time of sample collection (table 2). Routine samples were considered to represent baseflow if the total rainfall during the previous 5 days, as measured at the weather station in Rolling Fork, was less than 0.3 in. If the previous 5-day total rainfall amount was 0.3 in. or greater, samples were not used to determine summary statistics for baseflow. Runoff samples were all samples collected using automated samplers during runoff events.

During the 4-year study period, a Wilcoxon Rank-Sum statistical test indicated total nitrogen, nitrate plus nitrite, total phosphorus and suspended-sediment concentrations during runoff were significantly higher than concentrations during baseflow at both stations (table 2). This result is consistent with expected observations from a basin dominated by nonpoint source runoff. A between-station statistical comparison of total nitrogen, nitrate plus nitrite, total phosphorus and suspended-sediment concentrations indicated no significant differences in concentration between the stations during either baseflow or runoff.

\section{Seasonal Variation in Concentrations of Nutrients and Sediment}

Total nitrogen and total phosphorus concentrations in surface water can vary seasonally in agricultural watersheds because of the timing of fertilizer application and temporal variation in precipitation amounts (Storm and others, 2001). Greater and more frequent fertilizer application in the spring increases the probability of higher nutrient concentrations in streams during spring runoff. Concentrations of total nitrogen, nitrate plus nitrite, total phosphorus, orthophosphate, and suspended sediment for this study were seasonally grouped using the same criteria previously described: spring was considered to be February through May; summer, June through September; and fall, October through January.

Nutrient and sediment concentrations at the two study stations varied by season throughout each year of study (figs. 6-10). During baseflow conditions, concentrations of total nitrogen, nitrate plus nitrite, and total phosphorus tended to be highest in the spring at both Steele Bayou stations (figs. 6-8) and, except for total nitrogen at Steele Bayou near Glen Allan, typically had a wide range of concentrations. Baseflow concentrations of orthophosphate tended to be highest in the summer at both Steele Bayou Stations (fig. 9). During baseflow conditions, however, suspended sediment concentration did not vary seasonally at either Steele Bayou station (fig. 10).

During runoff conditions, concentrations of total nitrogen, nitrate plus nitrite, total phosphorus, and suspended sediment tended to be highest during the fall and spring, usually having a considerably wide range (figs. 6-8, 10). Runoff concentrations of orthophosphate tended to be highest in the fall and summer at both Steele Bayou stations (fig. 9). This is expected in an agriculture-dominated basin, with nutrient and sediment concentrations being greatest during periods of high runoff and streamflow (fall and spring), during times of fertilizer application (spring), and during times of little to no cover in some agricultural fields when cover crops are absent (fall).

Within-season variability of baseflow versus runoff concentrations of total nitrogen, nitrate plus nitrite, total phosphorus, orthophosphate and suspended sediment generally was greatest during the fall at both stations. In addition, baseflow concentrations were generally lower than runoff concentrations for all constituents during the fall. Concentrations typically varied less during the spring, with similar magnitudes and ranges observed between samples collected during baseflow and runoff. Two exceptions were for total nitrogen at Steele Bayou near Glen Allan and for suspended sediment at both stations; concentrations were markedly higher during runoff than during baseflow in both cases. This result is expected, because fertilizer application and high runoff occur during the spring.

Seasonal ratios of nitrate plus nitrite to total nitrogen (referred to as the $\mathrm{N}$ ratio) and orthophosphate to total phosphorus (referred to as the $\mathrm{P}$ ratio) are shown in figures 11 and 12. The seasonal distributions of $\mathrm{N}$ and $\mathrm{P}$ ratios differed between runoff and baseflow samples, and these differences varied seasonally (figs. 11 and 12). At both Steele Bayou stations, baseflow $\mathrm{N}$ ratios were generally lower in the fall and summer (median $\mathrm{N}$ ratios 4-5 percent) than in the spring (median $\mathrm{N}$ ratios both 35 percent). The spring was also the only season when $\mathrm{N}$ ratios were frequently higher for baseflow than runoff (fig. 11). Conversely, for all seasons at both stations, $P$ ratios were frequently higher for baseflow than runoff (fig. 12). Baseflow P ratios were highest in the summer at both stations, with median $\mathrm{P}$ ratios between 40 and 50 percent. The higher $\mathrm{N}$ ratios during baseflow in the spring may be explained by the timing of fertilizer application and rainfall patterns.

Seasonal patterns of $\mathrm{P}$ ratios between baseflow and runoff were the opposite of patterns observed for $\mathrm{N}$ ratios in the fall and summer. The consistently higher $\mathrm{P}$ ratios typically observed in baseflow compared to runoff during all seasons may be due to the soil of the Steele Bayou Basin typically being high enough in phosphorus content that the application of phosphorus as fertilizer is not necessary. Phosphorus is readily absorbed and attached to sediment, usually in organic form, and thus ratios are more consistent with seasonal rainfall and runoff patterns. 
Table 2. Summary statistics of total nitrogen, nitrite plus nitrate, total phosphorus, orthophosphate and suspended sediment concentrations in water-quality samples collected during baseflow and runoff conditions at water-quality stations in the Steele Bayou Basin, Mississippi, 0ctober 2010 through September 2014.

[USGS, U.S. Geological Survey; Obs., number of observations; mg/L, milligrams per liter; N, nitrogen; P, phosphorus; MS, Mississippi]

\begin{tabular}{|c|c|c|c|c|c|c|c|c|c|c|}
\hline \multirow{2}{*}{$\begin{array}{l}\text { USGS station } \\
\text { name (number) }\end{array}$} & \multicolumn{4}{|c|}{ Baseflow concentrations } & \multirow{2}{*}{ Obs. } & \multicolumn{4}{|c|}{ Runoff concentrations } & \multirow{2}{*}{$\begin{array}{l}\text { Number } \\
\text { of storms }\end{array}$} \\
\hline & Minimum & Median & Mean & Maximum & & Minimum & Median & Mean & Maximum & \\
\hline \multicolumn{11}{|c|}{ Total nitrogen (mg/L as N) } \\
\hline $\begin{array}{l}\text { Steele Bayou near } \\
\quad \text { Glen Allan, MS (07288847) }\end{array}$ & 0.62 & 1.4 & 1.4 & 2.3 & 15 & 0.9 & 3.0 & 3.2 & 9.1 & 9 \\
\hline $\begin{array}{c}\text { Steele Bayou at Grace Road at } \\
\text { Hopedale, MS (07288860) }\end{array}$ & 0.58 & 1.1 & 1.5 & 4.2 & 15 & 0.8 & 2.6 & 2.6 & 6.7 & 14 \\
\hline \multicolumn{11}{|c|}{ Total phosphorus (mg/L as P) } \\
\hline $\begin{array}{l}\text { Steele Bayou near } \\
\text { Glen Allan, MS (07288847) }\end{array}$ & 0.11 & 0.25 & 0.28 & 0.84 & 15 & 0.14 & 0.80 & 0.76 & 1.65 & 9 \\
\hline $\begin{array}{c}\text { Steele Bayou at Grace Road at } \\
\text { Hopedale, MS (07288860) }\end{array}$ & 0.09 & 0.21 & 0.27 & 0.80 & 15 & 0.18 & 0.60 & 0.63 & 1.63 & 14 \\
\hline \multicolumn{11}{|c|}{ Nitrite + nitrate $(\mathrm{mg} / \mathrm{L})$} \\
\hline $\begin{array}{l}\text { Steele Bayou near } \\
\quad \text { Glen Allan, MS (07288847) }\end{array}$ & 0.02 & 0.09 & 0.35 & 0.84 & 15 & 0.09 & 0.85 & 0.88 & 2.28 & 9 \\
\hline $\begin{array}{c}\text { Steele Bayou at Grace Road at } \\
\text { Hopedale, MS (07288860) }\end{array}$ & 0.02 & 0.05 & 0.26 & 1.09 & 15 & 0.02 & 0.65 & 0.69 & 1.93 & 14 \\
\hline \multicolumn{11}{|c|}{ Orthophosphate (mg/L) } \\
\hline $\begin{array}{l}\text { Steele Bayou near } \\
\quad \text { Glen Allan, MS (07288847) }\end{array}$ & 0.03 & 0.07 & 0.09 & 0.19 & 15 & 0.05 & 0.09 & 0.10 & 0.20 & 9 \\
\hline $\begin{array}{c}\text { Steele Bayou at Grace Road at } \\
\text { Hopedale, MS (07288860) }\end{array}$ & 0.01 & 0.06 & 0.07 & 0.17 & 15 & 0.02 & 0.08 & 0.09 & 0.18 & 14 \\
\hline \multicolumn{11}{|c|}{ Suspended sediment (mg/L) } \\
\hline $\begin{array}{l}\text { Steele Bayou near } \\
\quad \text { Glen Allan, MS (07288847) }\end{array}$ & 55 & 87 & 146 & 372 & 11 & 9 & 490 & 595 & 1,950 & 12 \\
\hline $\begin{array}{c}\text { Steele Bayou at Grace Road at } \\
\text { Hopedale, MS (07288860) }\end{array}$ & 13 & 28 & 39 & 305 & 11 & 69 & 430 & 473 & 2,040 & 18 \\
\hline
\end{tabular}



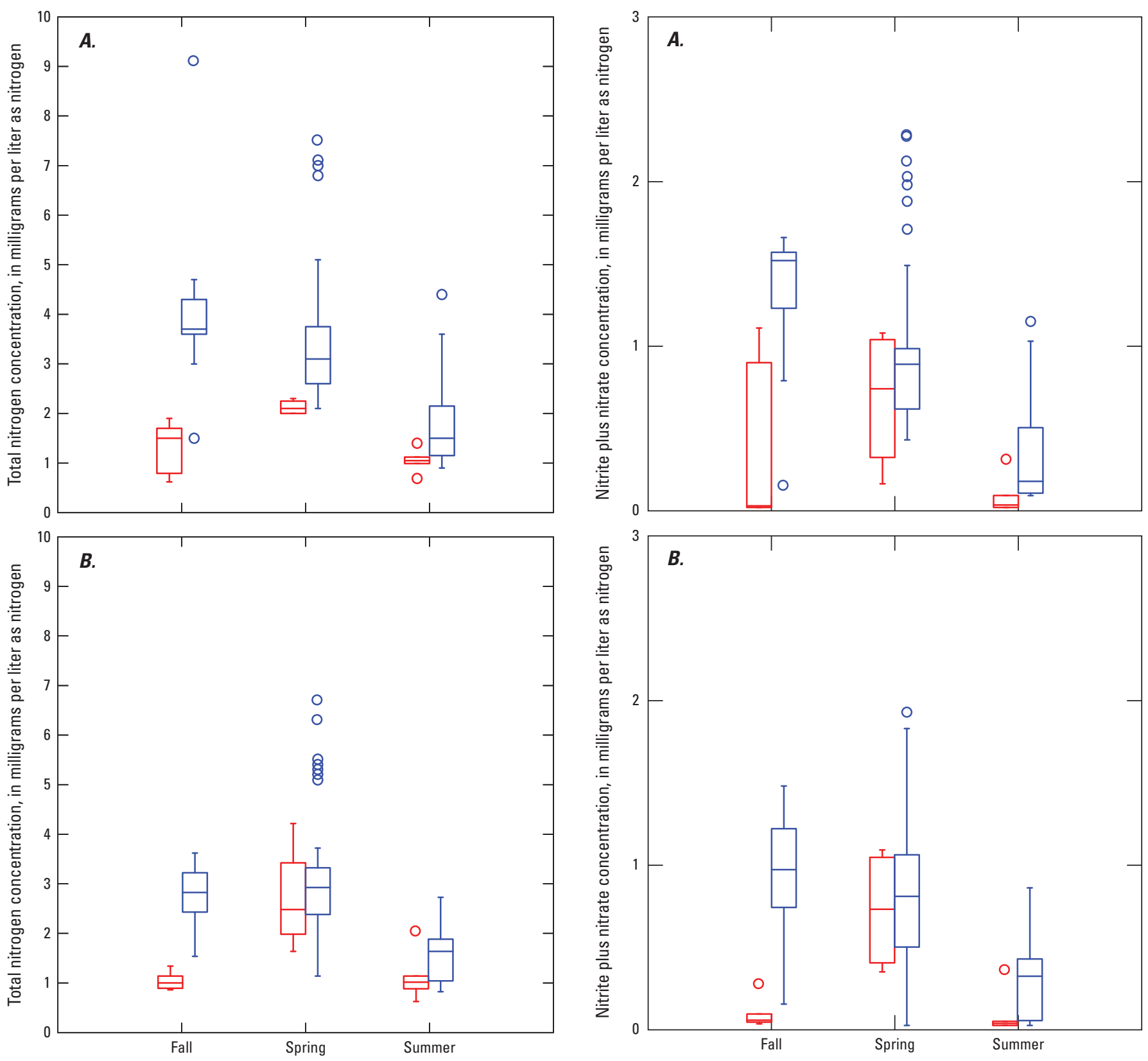

EXPLANATION

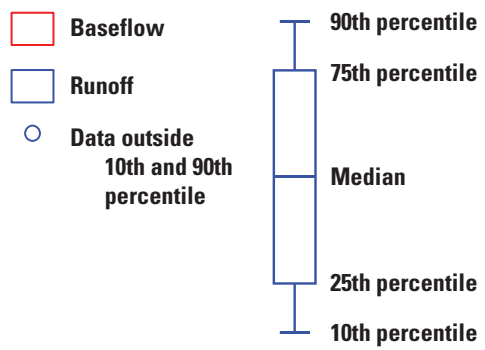

EXPLANATION

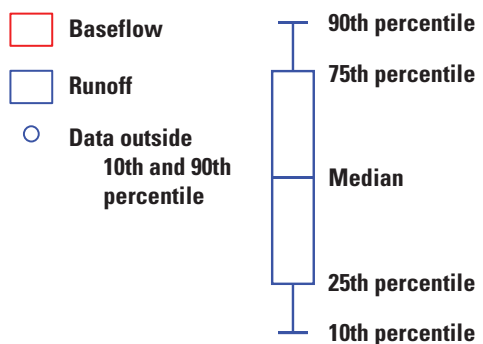

Figure 6. Seasonal distributions of total nitrogen concentrations in water-quality samples collected during baseflow and runoff conditions at the, $A$, Steele Bayou near Glen Allan, MS, and, $B$, Steele Bayou at Grace Road at Hopedale, MS, water-quality stations in the Steele Bayou Basin, Mississippi, water years 2011-14.

Figure 7. Seasonal distributions of nitrate plus nitrite concentrations in water-quality samples collected during baseflow and runoff conditions at the, $A$, Steele Bayou near Glen Allan, MS, and, $B$, Steele Bayou at Grace Road at Hopedale, MS, water-quality stations in the Steele Bayou Basin, Mississippi, water years 2011-14. 

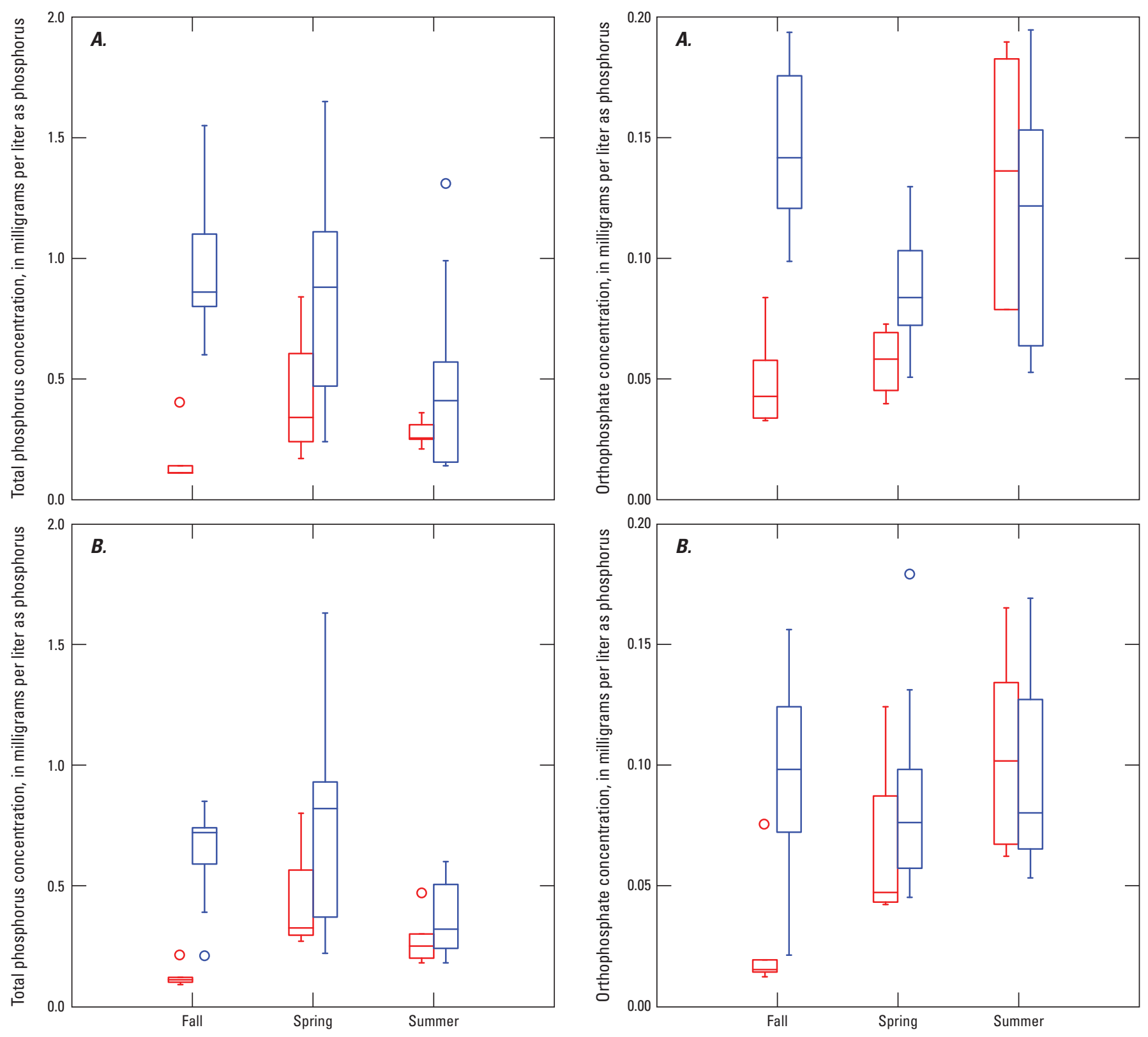

EXPLANATION

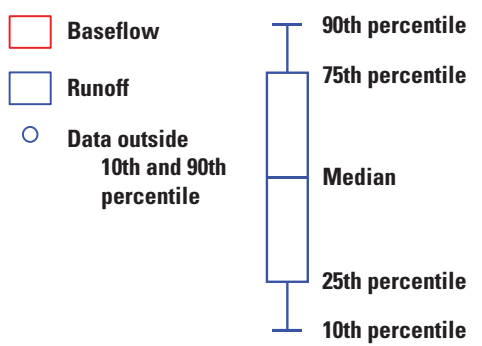

Figure 8. Seasonal distributions of total phosphorus concentrations in water-quality samples collected during baseflow and runoff conditions at the, $A$, Steele Bayou near Glen Allan, MS, and, $B$, Steele Bayou at Grace Road at Hopedale, MS, water-quality stations in the Steele Bayou Basin, Mississippi, water years 2011-14.

Figure 9. Seasonal distributions of orthophosphate concentrations in water-quality samples collected during baseflow and runoff conditions at the, $A$, Steele Bayou near Glen Allan, MS, and, $B$, Steele Bayou at Grace Road at Hopedale, MS, water-quality stations in the Steele Bayou Basin, Mississippi, water years 2011-14. 

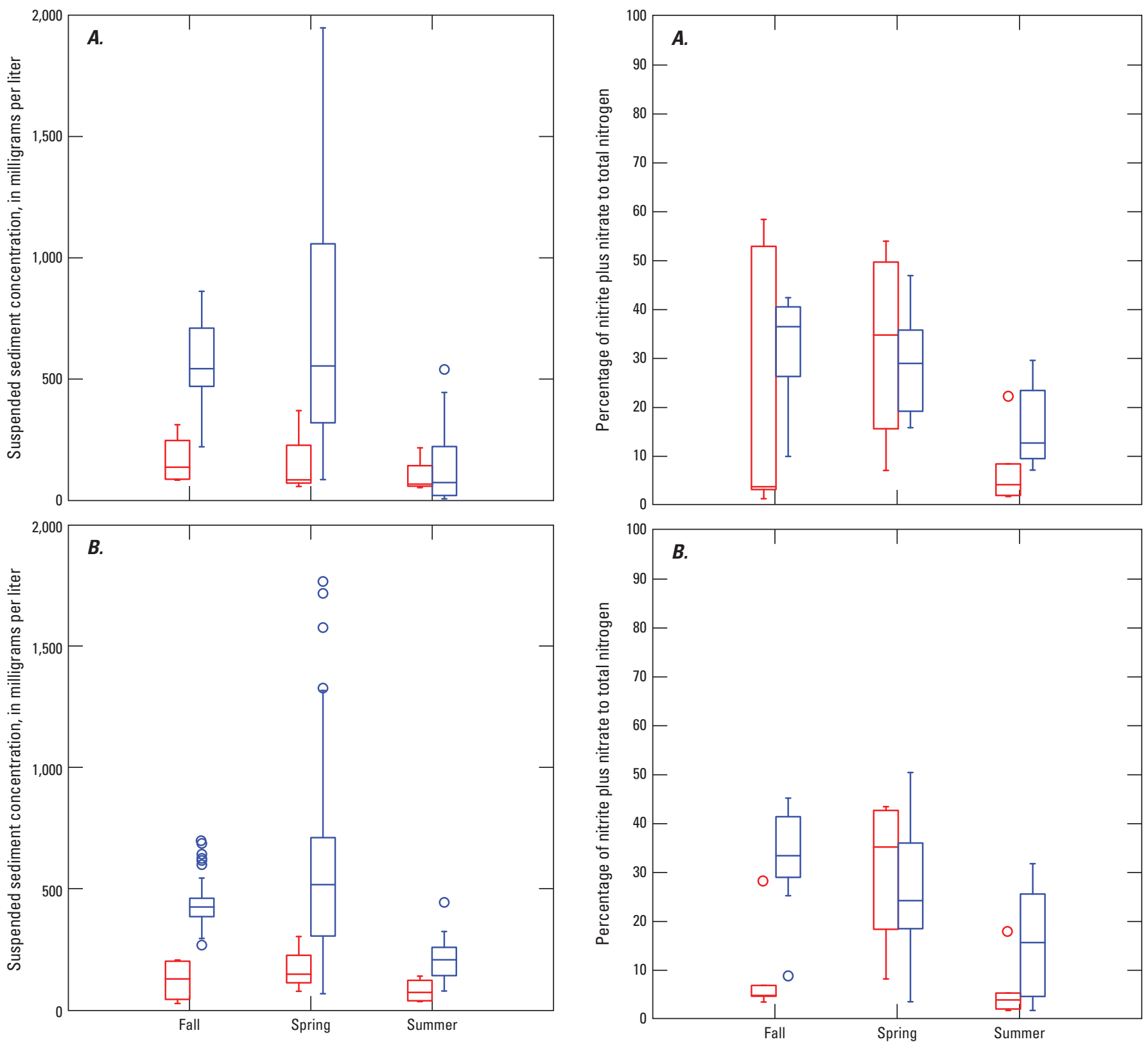

EXPLANATION

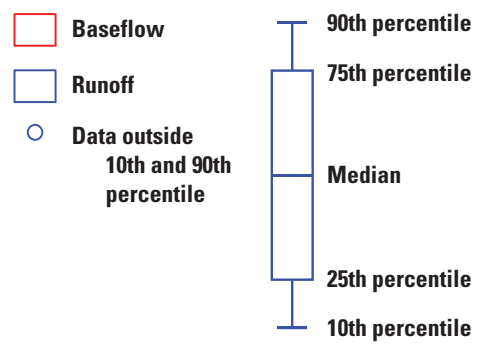

Figure 10. Seasonal distributions of suspended sediment concentrations in water-quality samples collected during baseflow and runoff conditions at the, $A$, Steele Bayou near Glen Allan, MS, and, $B$, Steele Bayou at Grace Road at Hopedale, MS, water-quality stations in the Steele Bayou Basin, Mississippi, water years 2011-14. 

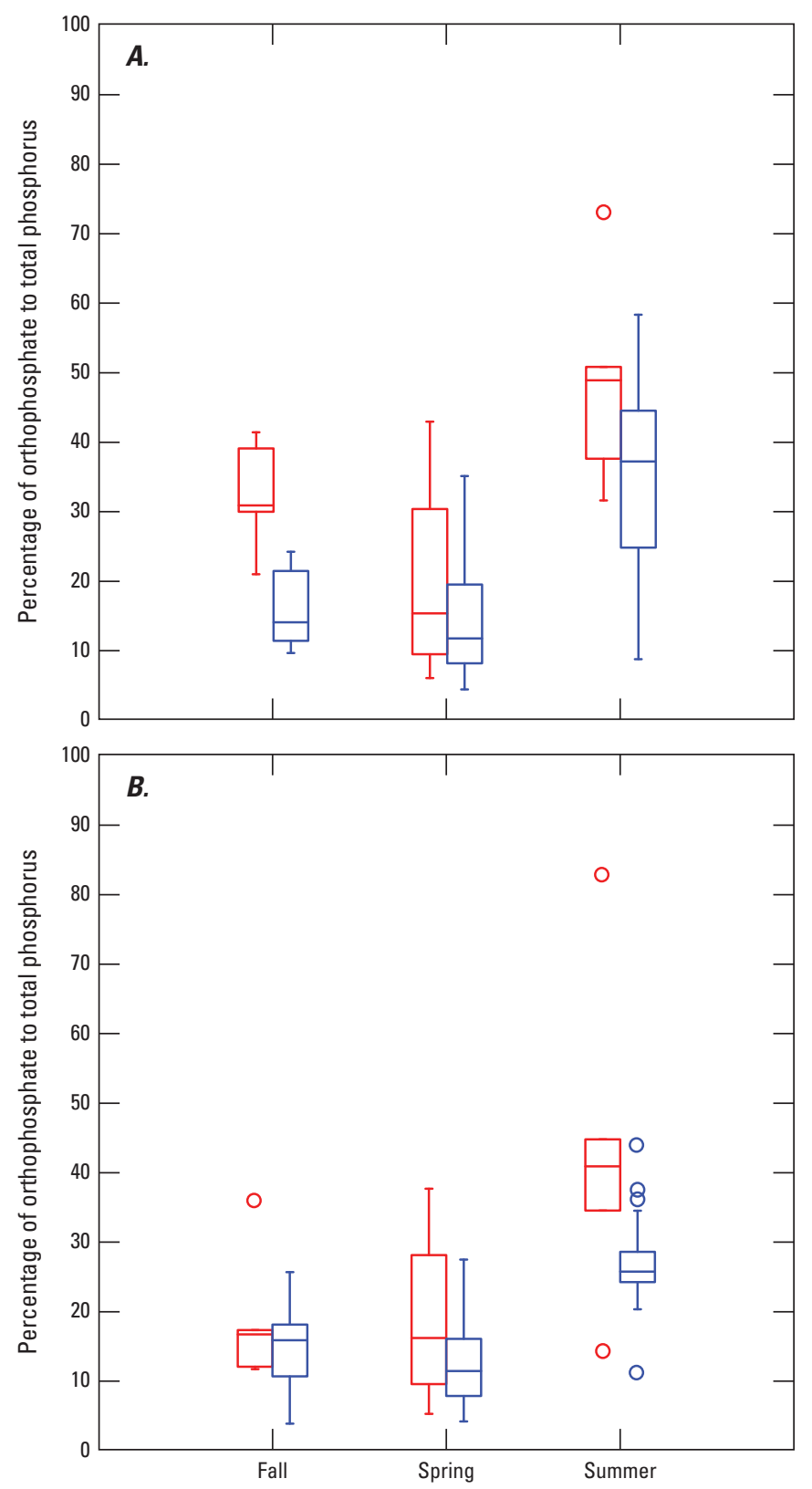

EXPLANATION

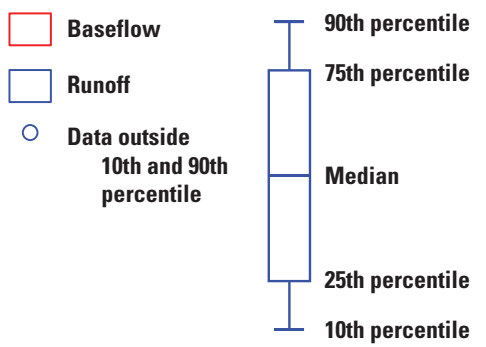

Figure 12. Seasonal ratios of orthophosphate to total phosphorus at the, $A$, Steele Bayou near Glen Allan, MS, and, $B$, Steele Bayou at Grace Road at Hopedale, MS, water-quality stations in the Steele Bayou Basin, Mississippi, water years 2011-14.

\section{Estimated Loads and Yields of Nutrients and Sediment}

Load represents the mass (usually in pounds or tons) of a waterborne constituent moving past a given point per unit of time. Yields are defined as the amount of load per unit area and are useful for comparing basins having different drainage areas. At the two Steele Bayou stations, average annual loads (in metric tons per year) for nutrients and sediment were estimated using linear regression models calibrated with samples collected between October 2010 and September 2014. The linear regression models developed to estimate loads of total nitrogen, nitrate plus nitrite, total phosphorus, orthophosphate, and suspended sediment are listed in table 3.

Generalized $\mathrm{R}^{2}$ values were at least 88 percent for all models for Steele Bayou at Hopedale and Steele Bayou near Glen Allan (table 3). Bias statistics indicated an elevated bias of about 28 percent to 25 percent in estimates of nitrate plus nitrite and suspended sediment, respectively, at Steele Bayou near Glen Allan, and of about 24 percent in estimates of nitrate plus nitrite at Steele Bayou near Hopedale (table 3). All other models produced estimates that were biased by no more than 8 percent, on average. Only one model used a flow anomaly term at Steele Bayou near Glen Allan, whereas all the models at Steele Bayou near Hopedale used flow anomaly terms in place of daily streamflow. In addition, over half of the models used seasonal terms. A time-trend term was used in 3 models and hysteresis term was used in 2 models (table 3 ). Loads were initially estimated in metric tons per day and then aggregated to annual and seasonal loads.

\section{Annual Loads and Yields of Nutrients and Sediment}

Overall, loads for nutrients and sediment varied annually, with the largest loads observed in water years 2013-14 and the smallest loads observed in water year 2011 for all constituents at both stations (tables 4-8). Average annual yields were largest for all constituents at the upstream station, Steele Bayou near Glen Allan; however, the differences in yields between stations were minimal (less than 9 percent) for total nitrogen, total phosphorus, and orthophosphate. Differences were greater for nitrate plus nitrite and suspendedsediment yields, which were 34 and 38 percent larger, respectively, at Steele Bayou near Glen Allan than at Steele Bayou at Hopedale (tables 5 and 8). Differences in yields between stations varied from year to year. Total nitrogen, total phosphorus and orthophosphate yields were greatest at Steele Bayou near Glen Allan in 2012 and 2014 and were greatest at Steele Bayou at Hopedale in 2011 and 2013. Nitrate plus nitrite yields were largest at Steele Bayou near Glen Allan in 2012, 2013, and 2014. Sediment yields were larger at Steele Bayou near Glen Allan in 2013 and 2014 and were larger at Steele Bayou at Hopedale in 2011 and 2012. Possible explanations for the observation of larger yields 
Table 3. Regression models used for estimating total nitrogen, nitrite plus nitrate, total phosphorus, orthophosphate and suspended sediment concentration loads at waterquality stations sampled in the Steele Bayou Basin, Mississippi, October 2010 to September 2014.

[USGS, U.S. Geological Survey; R2, coefficient of determination; MS, Mississippi; ln, natural logarithm; L, daily load in tons per day; Q, mean daily streamflow in cubic feet per second; sin, sine; cos, cosine. The standard error of the estimate is reported in natural logarithm units; therefore, this value, multiplied by 100 , can be interpreted roughly as the average percent error]

\begin{tabular}{|c|c|c|c|c|c|c|c|}
\hline $\begin{array}{l}\text { USGS station } \\
\text { name (number) }\end{array}$ & Constituent & $\begin{array}{l}\text { Total sample } \\
\text { count (cen- } \\
\text { sored count) }\end{array}$ & Regression equation & $\begin{array}{l}\text { Residual } \\
\text { variance }\end{array}$ & $\begin{array}{l}\text { Generalized } \\
R^{2} \text { (percent) }\end{array}$ & $\begin{array}{c}\text { Bias } \\
\text { (percent) }\end{array}$ & $\begin{array}{l}\text { E (Nash- } \\
\text { Sutcliffe } \\
\text { model } \\
\text { efficiency) }\end{array}$ \\
\hline $\begin{array}{l}\text { Steele Bayou near } \\
\text { Glen Allan, MS (07288847) }\end{array}$ & & $40(4)$ & $\begin{array}{l}\ln (\mathrm{L})=6.67306+1.08843 * \ln \mathrm{l}+0.38501 * \sin (\mathrm{TIME} * 2 * \mathrm{pi}) \\
\quad+0.20674 * \cos (\mathrm{TIME} * 2 * \mathrm{pi})+0.12958 * \mathrm{dQ} 7+ \\
\quad 0.07577 * \mathrm{dQ} 7{ }^{\wedge} 2\end{array}$ & 0.1 & 97.7 & 0.3 & 0.8 \\
\hline $\begin{array}{l}\text { Steele Bayou at Grace Road at } \\
\text { Hopedale, MS (07288860) }\end{array}$ & Total nitrogen & $48(2)$ & $\begin{array}{l}\ln (\mathrm{L})=5.9943+1.1588 * \mathrm{a} 3 \mathrm{mo}+1.0375 * \mathrm{a} 3 \mathrm{mo} \_\mathrm{HFV}+ \\
0.2685 * \sin (\mathrm{TIME} * 2 * \mathrm{pi})+0.2378 * \cos \left(\mathrm{TIME}^{*} 2 * \mathrm{pi}\right)+ \\
\quad 0.1628 * \mathrm{dQ} 3\end{array}$ & 0.1 & 97.5 & 5.5 & 0.8 \\
\hline $\begin{array}{l}\text { Steele Bayou near } \\
\quad \text { Glen Allan, MS (07288847) }\end{array}$ & \multirow{2}{*}{ Total phosphorus } & $40(0)$ & $\ln (\mathrm{L})=5.2853+1.2400 * \ln \mathrm{Q}+0.1886 * \mathrm{cTIME}$ & 0.4 & 93.9 & -7.0 & 0.8 \\
\hline $\begin{array}{l}\text { Steele Bayou at Grace Road at } \\
\text { Hopedale, MS (07288860) }\end{array}$ & & $48(0)$ & $\begin{array}{c}\ln (\mathrm{L})=4.5473+1.3208 * \mathrm{a} 3 \mathrm{mo}+1.2002 * \mathrm{a} 3 \mathrm{mo} \_\mathrm{HFV}+ \\
0.1623 * \sin \left(\mathrm{TIME}^{*} 2 * \mathrm{pi}\right)+0.1996 * \cos \left(\mathrm{TIME}^{*} 2 * \mathrm{pi}\right)\end{array}$ & 0.1 & 97.8 & 2.6 & 0.9 \\
\hline $\begin{array}{l}\text { Steele Bayou near } \\
\quad \text { Glen Allan, MS (07288847) }\end{array}$ & \multirow{2}{*}{ Nitrite + nitrate } & $35(3)$ & $\begin{array}{l}\ln (\mathrm{L})=4.0658+0.7691 * \mathrm{a} 1 \mathrm{mo}+1.3862 * \mathrm{a} 1 \mathrm{mo} \_\mathrm{HFV}+ \\
0.6503 * \sin \left(\mathrm{TIME}^{*} 2 * \mathrm{pi}\right)+0.8304 * \cos \left(\mathrm{TIME}^{*} 2 * \mathrm{pi}\right)\end{array}$ & 0.8 & 91.1 & 27.6 & 0.2 \\
\hline $\begin{array}{l}\text { Steele Bayou at Grace Road at } \\
\text { Hopedale, MS (07288860) }\end{array}$ & & $34(2)$ & $\begin{array}{l}\ln (\mathrm{L})=3.1124+1.6514 * \mathrm{a} 9 \mathrm{mo}+1.4199 * \mathrm{a} 9 \mathrm{mo} \_\mathrm{HFV}+ \\
\quad 0.5078 * \text { cTIME }\end{array}$ & 0.7 & 91.2 & 24.2 & 0.7 \\
\hline $\begin{array}{l}\text { Steele Bayou near } \\
\quad \text { Glen Allan, MS (07288847) }\end{array}$ & \multirow{2}{*}{ Orthophosphate } & $40(0)$ & $\begin{array}{l}\ln (\mathrm{L})=4.01504+1.15797 * \ln \mathrm{Q}+-0.04394 * \ln \mathrm{Q}^{\wedge} 2+ \\
\quad-0.34983 * \sin (\mathrm{TIME} * 2 * \mathrm{pi})+0.03405 * \cos \left(\mathrm{TIME}^{*} 2 * \mathrm{pi}\right)\end{array}$ & 0.1 & 97.6 & 3.3 & 1.0 \\
\hline $\begin{array}{l}\text { Steele Bayou at Grace Road at } \\
\text { Hopedale, MS (07288860) }\end{array}$ & & $34(0)$ & $\begin{array}{l}\ln (\mathrm{L})=3.06959+1.25074 * \mathrm{a} 3 \mathrm{mo}+1.11369 * \mathrm{a} 3 \mathrm{mo} / \mathrm{HFV}+ \\
\quad-0.32872 * \sin \left(\mathrm{TIME}^{*} 2 * \mathrm{pi}\right)+-0.06528 * \cos (\mathrm{TIME} * 2 * \mathrm{pi})\end{array}$ & 0.1 & 96.5 & 0.8 & 0.9 \\
\hline $\begin{array}{l}\text { Steele Bayou near } \\
\quad \text { Glen Allan, MS (07288847) }\end{array}$ & \multirow{2}{*}{$\begin{array}{l}\text { Suspended sedi- } \\
\text { ment }\end{array}$} & $58(0)$ & $\begin{array}{l}\ln (\mathrm{L})=10.9805+1.2976 * \operatorname{lnQ}+0.1124 * \ln \mathrm{Q}^{\wedge} 2 \\
\quad+0.2493 * \mathrm{cTIME}+0.2274 * \mathrm{cTIME} 2+ \\
\quad 0.2106 * \sin \left(\mathrm{TIME}^{*} 2 * \mathrm{pi}\right)+0.5159 * \cos \left(\mathrm{TIME}^{*} 2 * \mathrm{pi}\right)\end{array}$ & 0.8 & 91.3 & 24.7 & 0.5 \\
\hline $\begin{array}{l}\text { Steele Bayou at Grace Road at } \\
\text { Hopedale, MS (07288860) }\end{array}$ & & $58(0)$ & $\ln (\mathrm{L})=10.631+1.355 * \mathrm{a} 1 \mathrm{mo}+1.421 * \mathrm{a} 1 \mathrm{mo} \_\mathrm{HFV}$ & 0.6 & 88.0 & 7.7 & 0.5 \\
\hline
\end{tabular}


Table 4. Estimated annual total nitrogen loads and yields in the Steele Bayou Basin, Mississippi, October 2010 through September 2014.

[USGS, U.S. Geological Survey; $\mathrm{km}^{2}$, square kilometer; t/yr, metric ton per year; $\mathrm{t} / \mathrm{yr} / \mathrm{km}^{2}$, metric ton per year per square kilometer; MS, Mississippi]

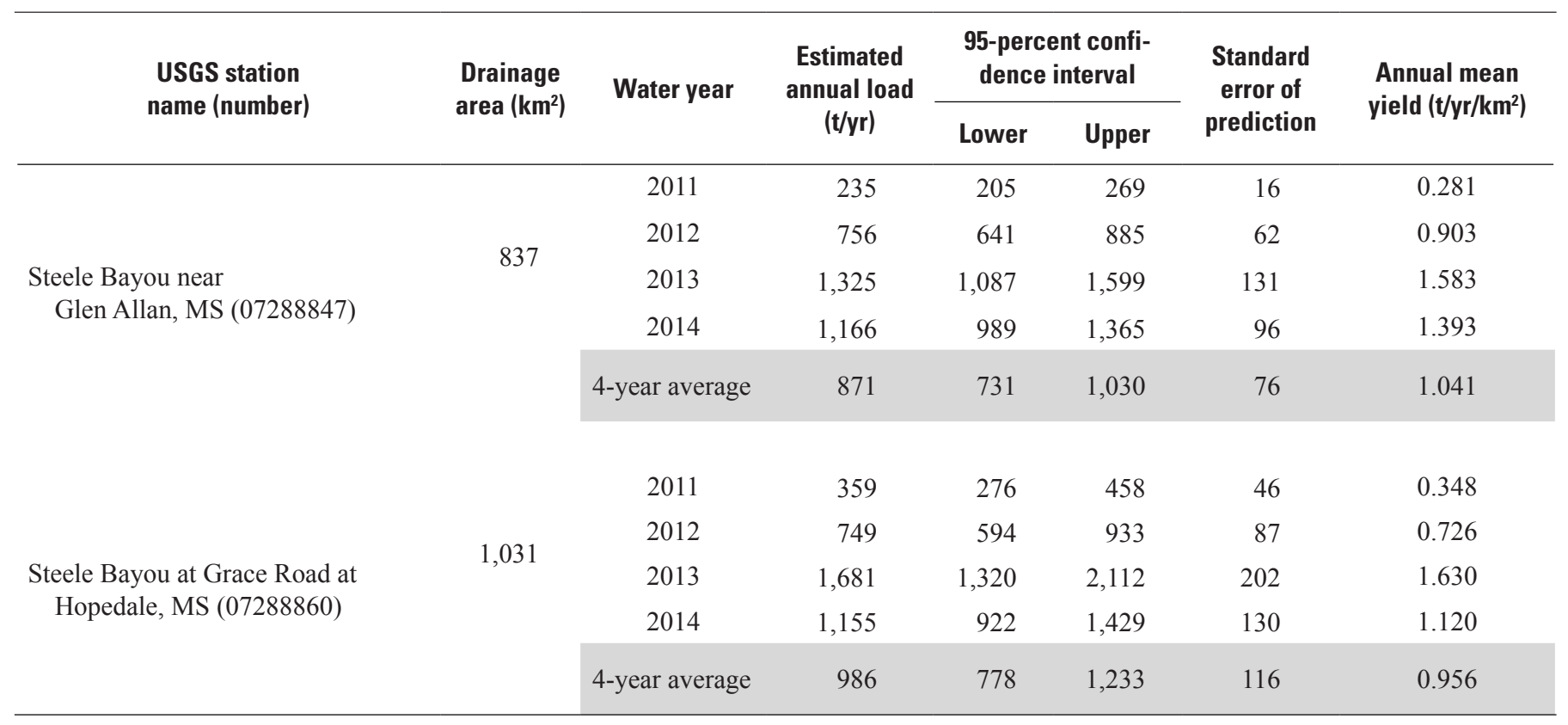

Table 5. Estimated annual nitrite plus nitrate loads and yields in the Steele Bayou Basin, Mississippi, October 2010 through September 2014.

[USGS, U.S. Geological Survey; $\mathrm{km}^{2}$, square kilometer; t/yr, metric ton per year; t/yr/km², metric ton per year per square kilometer; MS, Mississippi; —, unable to determine from available data]

\begin{tabular}{|c|c|c|c|c|c|c|c|}
\hline \multirow{2}{*}{$\begin{array}{l}\text { USGS station } \\
\text { name (number) }\end{array}$} & \multirow{2}{*}{$\begin{array}{l}\text { Drainage } \\
\text { area }\left(\mathbf{k m}^{2}\right)\end{array}$} & \multirow{2}{*}{ Water year } & \multirow{2}{*}{$\begin{array}{c}\text { Estimated } \\
\text { annual load } \\
\text { (t/yr) }\end{array}$} & \multicolumn{2}{|c|}{$\begin{array}{l}\text { 95-percent confi- } \\
\text { dence interval }\end{array}$} & \multirow{2}{*}{$\begin{array}{l}\text { Standard } \\
\text { error of } \\
\text { prediction }\end{array}$} & \multirow{2}{*}{$\begin{array}{l}\text { Annual mean } \\
\text { yield }\left(\mathrm{t} / \mathrm{yr} / \mathrm{km}^{2}\right)\end{array}$} \\
\hline & & & & Lower & Upper & & \\
\hline \multirow{3}{*}{$\begin{array}{l}\text { Steele Bayou near } \\
\quad \text { Glen Allan, MS (07288847) }\end{array}$} & \multirow{3}{*}{837} & 2011 & - & - & - & - & - \\
\hline & & 2012 & 308 & 165 & 527 & 93 & 0.368 \\
\hline & & 3 -year average & 363 & 196 & 618 & 109 & 0.366 \\
\hline \multirow{2}{*}{$\begin{array}{c}\text { Steele Bayou at Grace Road at } \\
\text { Hopedale, MS (07288860) }\end{array}$} & \multirow{2}{*}{1,031} & 2011 & - & - & - & - & - \\
\hline & & 3 -year average & 283 & 146 & 500 & 91 & 0.274 \\
\hline
\end{tabular}


Table 6. Estimated annual total phosphorus loads and yields in the Steele Bayou Basin, Mississippi, 0ctober 2010 through September 2014.

[USGS, U.S. Geological Survey; $\mathrm{km}^{2}$, square kilometer; t/yr, metric ton per year; t/yr/km², metric ton per year per square kilometer; MS, Mississippi]

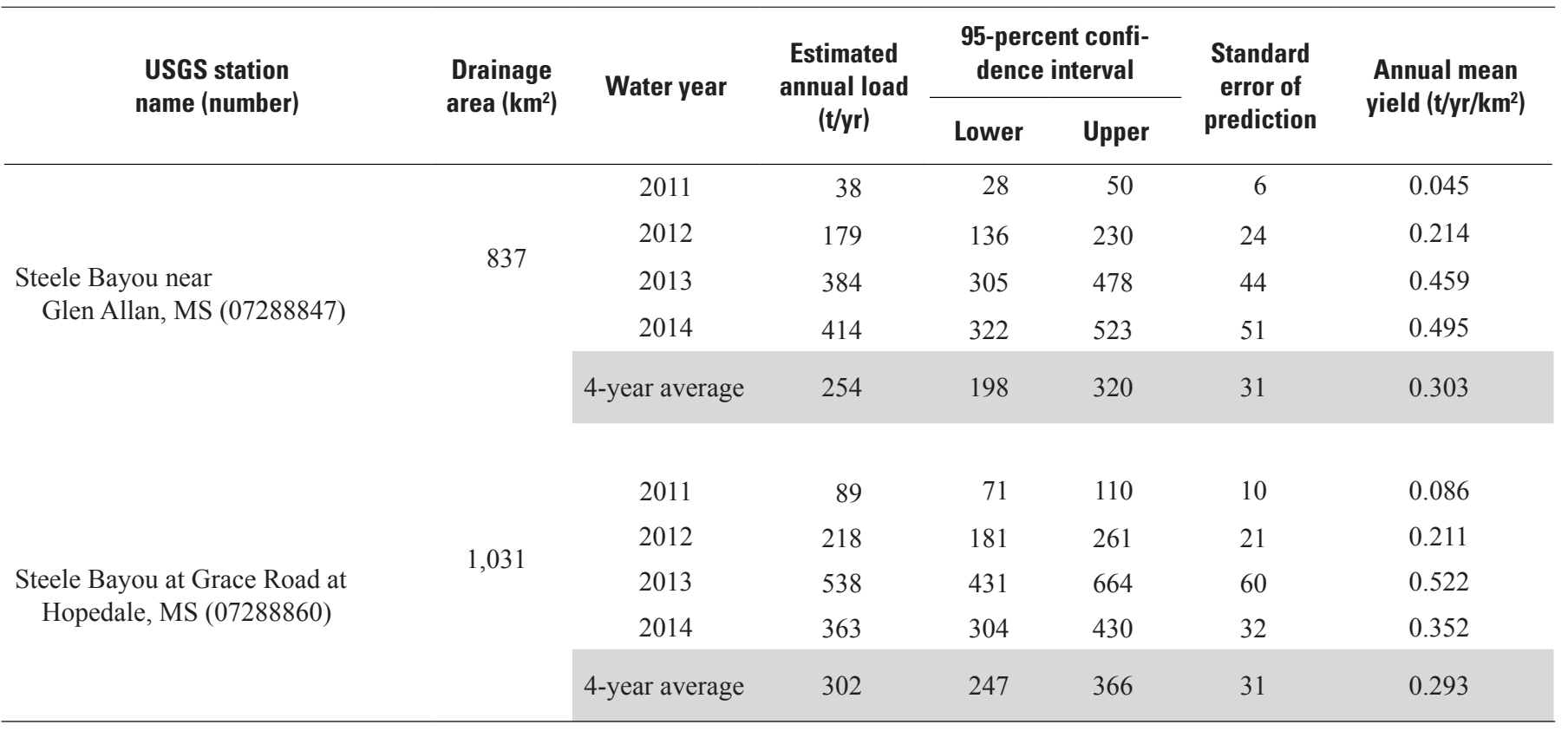

Table 7. Estimated annual orthophosphate loads and yields in the Steele Bayou Basin, Mississippi, October 2010 through September 2014.

[USGS, U.S. Geological Survey; km², square kilometer; t/yr, metric ton per year; t/yr/km², metric ton per year per square kilometer; MS, Mississippi]

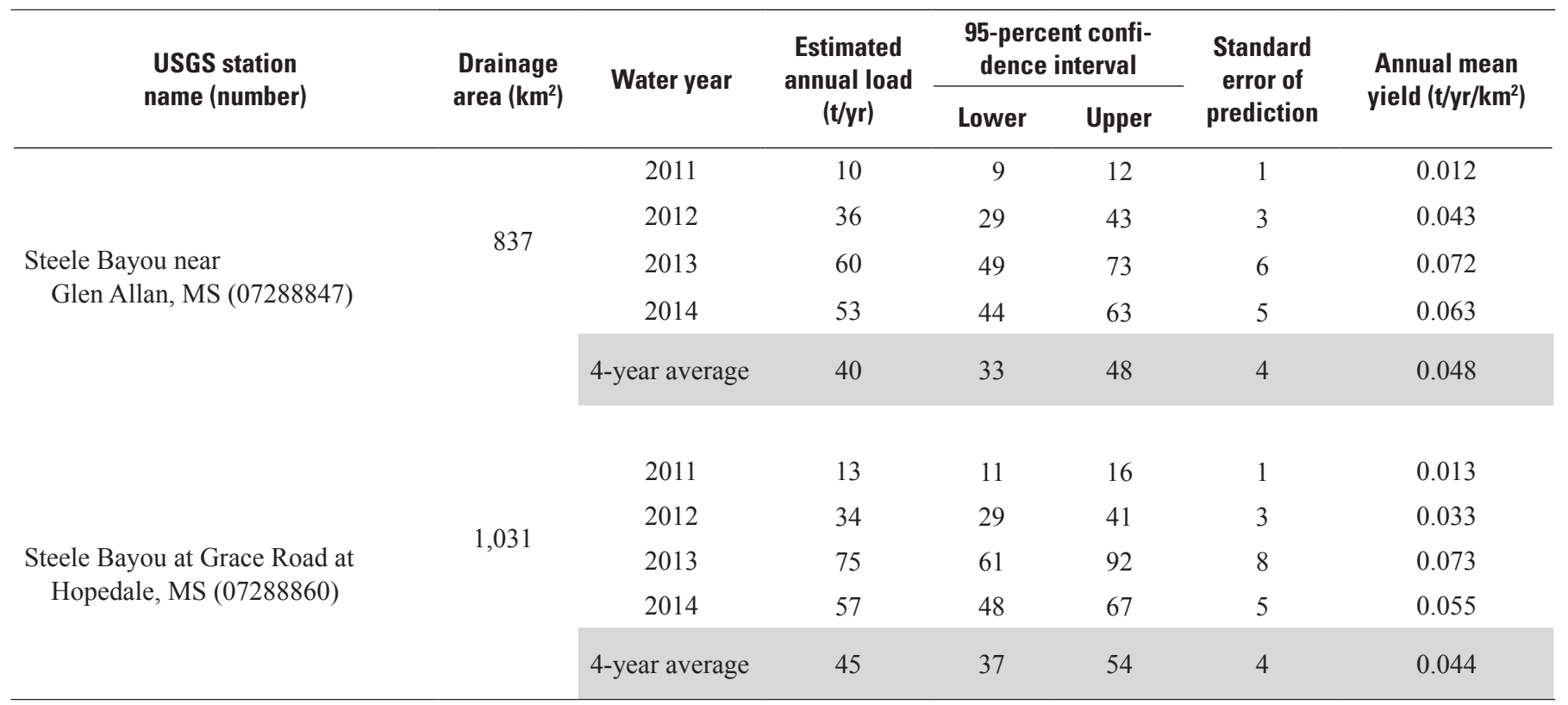


Table 8. Estimated suspended sediment loads and yields in the Steele Bayou Basin, Mississippi, October 2010 through September 2014.

[USGS, U.S. Geological Survey; $\mathrm{km}^{2}$, square kilometer; t/yr, metric ton per year; t/yr/km², metric ton per year per square kilometer; MS, Mississippi]

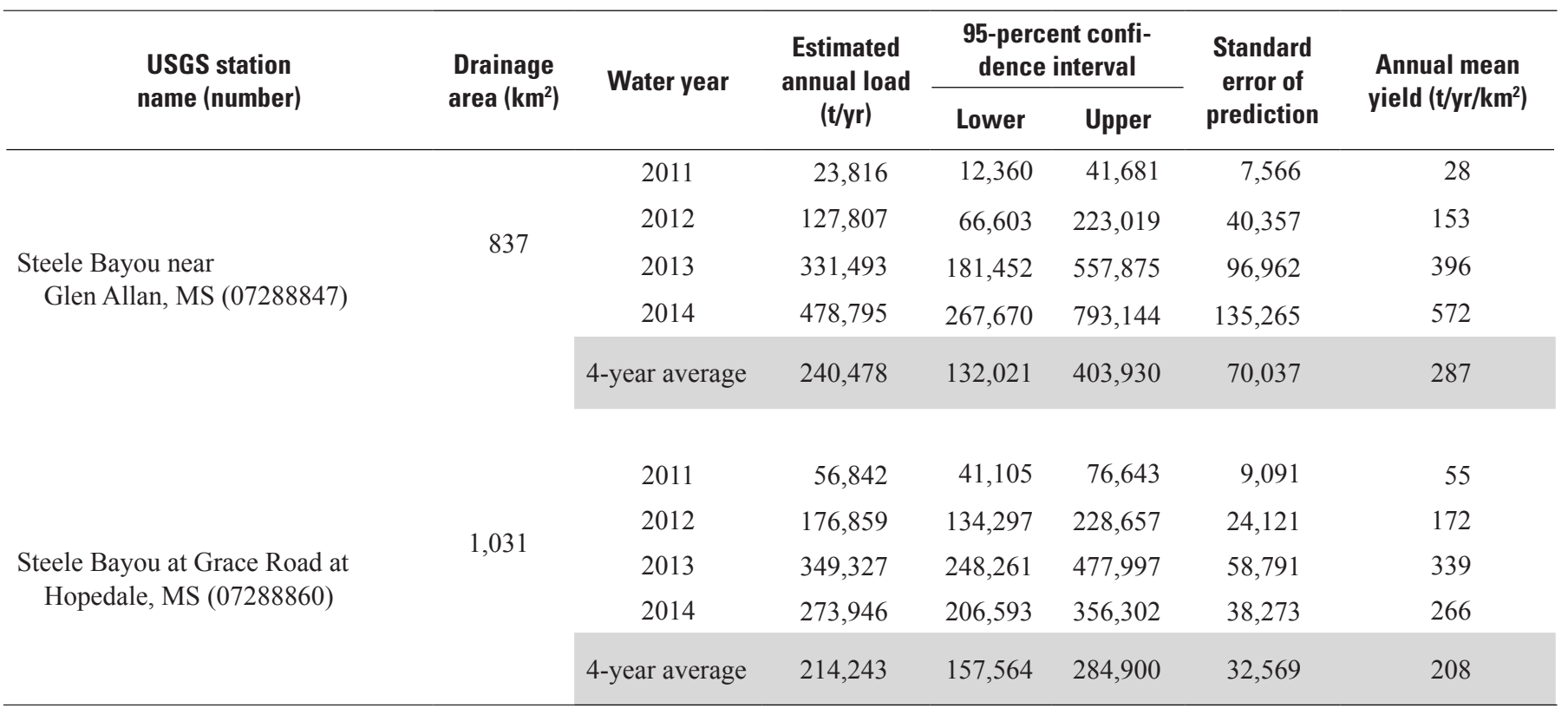

from the upstream station, especially nitrate plus nitrite and sediment, are dilution at the downstream station and proximity to sources. However, because phosphorus is not typically applied as fertilizer, unlike nitrate plus nitrite, differences between upstream and downstream loads and yields would not be expected, regardless of precipitation totals and associated runoff. Another explanation for the small differences in phosphorus yields between the sampling stations is the short distance between them, which may result in limited time for physical and (or) biogeochemical processes to occur.

\section{Seasonal Loads of Nutrients and Sediment}

Comparison of 3- or 4-year averages indicated seasonal loads were lowest in the summer, constituting no more than 20 percent of the annual load for all nutrients and suspended sediment at either station, in general (tables 9-13). At both stations, fall and spring average annual loads were consistently larger than summer loads for all nutrients and suspended sediment, with both seasons each contributing between 35 and 54 percent of the average annual load, depending on the station and constituent (tables 9-13). On average, loads were largest in the spring, when about 50 percent of the average annual load of all constituents was delivered to each station (tables 9-13). The exception was orthophosphate for which about 40 percent of the average annual load was delivered to each station in the spring (tables 9-13). Seasonal patterns in loads for all constituents were similar to seasonal patterns in concentrations. As with concentrations, seasonal patterns in loads probably reflect a combination of seasonal patterns in precipitation, runoff, streamflow, and timing of fertilizer application.

\section{Estimated Flow-Weighted Mean Concentrations of Nutrients and Sediment}

Flow-weighted mean (FWM) concentrations, determined by dividing total annual constituent loads by mean annual streamflow, are useful for evaluating trends in concentrations by reducing the influence of seasonal variability within streamflow data. The annual estimated FWM concentrations of total nitrogen, total phosphorus, and suspended sediment at the two stations in the Steele Bayou Basin from October 2010 through September 2014 are provided in tables 14-16. For water years 2012-14, the average FWM concentration of total nitrogen was about 16 percent lower at Steele Bayou at Hopedale than at Steele Bayou near Glen Allan, upstream. For water year 2011, the FWM concentration of total nitrogen at Steele Bayou near Glen Allan was about 10 percent higher than at Steele Bayou at Hopedale. Notably, the average precipitation for water year 2011 was about 31 percent less than the average for water years 2012-14. 
Table 9. Estimates of seasonal total nitrogen loads in the Steele Bayou Basin, Mississippi, October 2010 through September 2014.

[USGS, U.S. Geological Survey; estimated loads are in metric tons per season as nitrogen; MS, Mississippi; fall is October through January, spring is February through May, and summer is June through September]

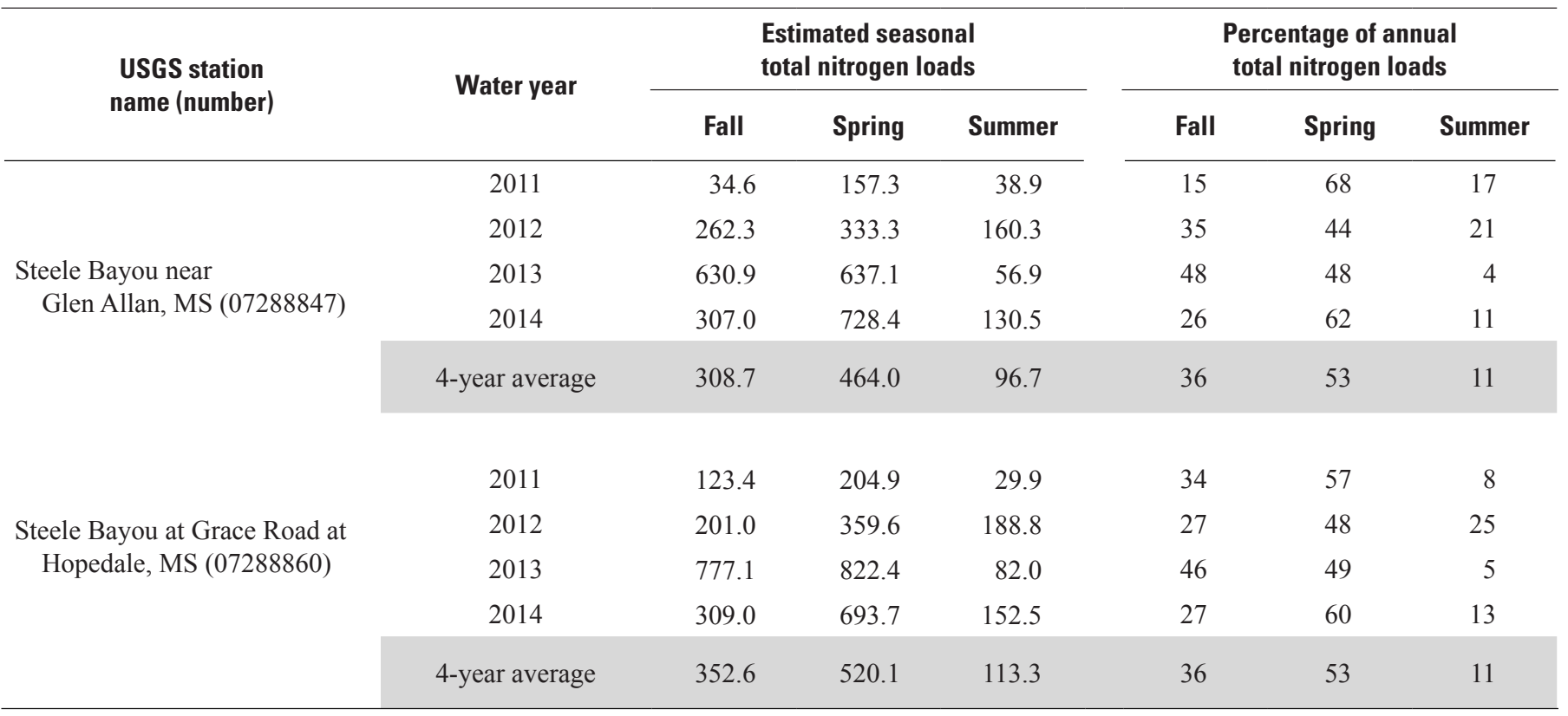

Table 10. Estimates of seasonal nitrite plus nitrate loads in the Steele Bayou Basin, Mississippi, October 2010 through September 2014.

[USGS, U.S. Geological Survey; estimated loads are in metric tons per season; MS, Mississippi; -, unable to determine from available data; fall is October through January, spring is February through May, and summer is June through September]

\begin{tabular}{|c|c|c|c|c|c|c|c|}
\hline \multirow{2}{*}{$\begin{array}{l}\text { USGS station } \\
\text { name (number) }\end{array}$} & \multirow{2}{*}{ Water year } & \multicolumn{3}{|c|}{$\begin{array}{l}\text { Estimated seasonal } \\
\text { nitrite + nitrate loads }\end{array}$} & \multicolumn{3}{|c|}{$\begin{array}{l}\text { Percentage of annual } \\
\text { nitrate }+ \text { nitrite loads }\end{array}$} \\
\hline & & Fall & Spring & Summer & Fall & Spring & Summer \\
\hline \multirow{4}{*}{$\begin{array}{l}\text { Steele Bayou near } \\
\quad \text { Glen Allan, MS (07288847) }\end{array}$} & 2011 & 33.6 & 82.3 & 8.8 & 27 & 66 & 7 \\
\hline & 2012 & 149.8 & 124.6 & 33.9 & 49 & 40 & 11 \\
\hline & 2013 & 222.0 & 153.9 & 8.9 & 58 & 40 & 2 \\
\hline & 4-year average & 128.4 & 157.4 & 17.7 & 42 & 52 & 6 \\
\hline \multirow{2}{*}{$\begin{array}{l}\text { Steele Bayou at Grace Road at } \\
\text { Hopedale, MS (07288860) }\end{array}$} & 2011 & - & - & - & - & - & - \\
\hline & 3-year average & 97.9 & 142.2 & 42.8 & 35 & 50 & 15 \\
\hline
\end{tabular}


Table 11. Estimates of seasonal total phosphorus loads in the Steele Bayou Basin, Mississippi, October 2010 through September 2014.

[USGS, U.S. Geological Survey; estimated loads are in metric tons per season; MS, Mississippi; fall is October through January, spring is February through May, and summer is June through September]

\begin{tabular}{|c|c|c|c|c|c|c|c|}
\hline \multirow{2}{*}{$\begin{array}{l}\text { USGS station } \\
\text { name (number) }\end{array}$} & \multirow{2}{*}{ Water year } & \multicolumn{3}{|c|}{$\begin{array}{l}\text { Estimated seasonal } \\
\text { total phosphorus loads }\end{array}$} & \multicolumn{3}{|c|}{$\begin{array}{l}\text { Percentage of annual } \\
\text { total phosphorus loads }\end{array}$} \\
\hline & & Fall & Spring & Summer & Fall & Spring & Summer \\
\hline \multirow{5}{*}{$\begin{array}{l}\text { Steele Bayou near } \\
\text { Glen Allan, MS (07288847) }\end{array}$} & 2011 & 4.3 & 25.6 & 8.2 & 11 & 67 & 22 \\
\hline & 2012 & 63.5 & 60.9 & 54.3 & 36 & 34 & 30 \\
\hline & 2013 & 200.6 & 162.3 & 21.0 & 52 & 42 & 5 \\
\hline & 2014 & 111.8 & 233.6 & 68.1 & 27 & 56 & 16 \\
\hline & 4-year average & 95.0 & 120.6 & 47.8 & 36 & 46 & 18 \\
\hline \multirow{5}{*}{$\begin{array}{l}\text { Steele Bayou at Grace Road at } \\
\text { Hopedale, MS (07288860) }\end{array}$} & 2011 & 29.2 & 53.0 & 7.1 & 33 & 59 & 8 \\
\hline & 2012 & 66.6 & 96.8 & 54.8 & 31 & 44 & 25 \\
\hline & 2013 & 269.8 & 246.1 & 22.3 & 50 & 46 & 4 \\
\hline & 2014 & 94.3 & 220.1 & 48.5 & 26 & 61 & 13 \\
\hline & 4-year average & 115.0 & 154.0 & 33.2 & 38 & 51 & 11 \\
\hline
\end{tabular}

Table 12. Estimates of seasonal orthophosphate loads in the Steele Bayou Basin, Mississippi, October 2010 through September 2014.

[USGS, U.S. Geological Survey; estimated loads are in metric tons per season; MS, Mississippi; fall is October through January, spring is February through May, and summer is June through September]

\begin{tabular}{|c|c|c|c|c|c|c|c|}
\hline \multirow{2}{*}{$\begin{array}{l}\text { USGS station } \\
\text { name (number) }\end{array}$} & \multirow{2}{*}{ Water year } & \multicolumn{3}{|c|}{$\begin{array}{l}\text { Estimated seasonal } \\
\text { orthophosphate loads }\end{array}$} & \multicolumn{3}{|c|}{$\begin{array}{l}\text { Percentage of annual orthophos- } \\
\text { phate loads }\end{array}$} \\
\hline & & Fall & Spring & Summer & Fall & Spring & Summe \\
\hline \multirow{5}{*}{$\begin{array}{l}\text { Steele Bayou near } \\
\text { Glen Allan, MS (07288847) }\end{array}$} & 2011 & 1.44 & 5.60 & 3.09 & 14 & 55 & 31 \\
\hline & 2012 & 13.72 & 9.69 & 12.28 & 38 & 27 & 34 \\
\hline & 2013 & 35.26 & 20.28 & 4.77 & 58 & 34 & 8 \\
\hline & 2014 & 21.38 & 21.43 & 10.26 & 40 & 40 & 19 \\
\hline & 4-year average & 17.95 & 14.25 & 7.60 & 45 & 36 & 19 \\
\hline \multirow{5}{*}{$\begin{array}{l}\text { Steele Bayou at Grace Road at } \\
\text { Hopedale, MS (07288860) }\end{array}$} & 2011 & 3.54 & 6.80 & 2.35 & 28 & 54 & 19 \\
\hline & 2012 & 9.58 & 10.87 & 14.03 & 28 & 32 & 41 \\
\hline & 2013 & 40.26 & 28.97 & 5.91 & 54 & 39 & 8 \\
\hline & 2014 & 18.99 & 25.95 & 12.06 & 33 & 46 & 21 \\
\hline & 4-year average & 18.09 & 18.15 & 8.59 & 40 & 40 & 19 \\
\hline
\end{tabular}


Table 13. Estimates of seasonal suspended sediment loads in the Steele Bayou Basin, Mississippi, October 2010 through September 2014.

[USGS, U.S. Geological Survey; estimated loads are in metric tons per season; MS, Mississippi; fall is October through January, spring is February through May, and summer is June through September]

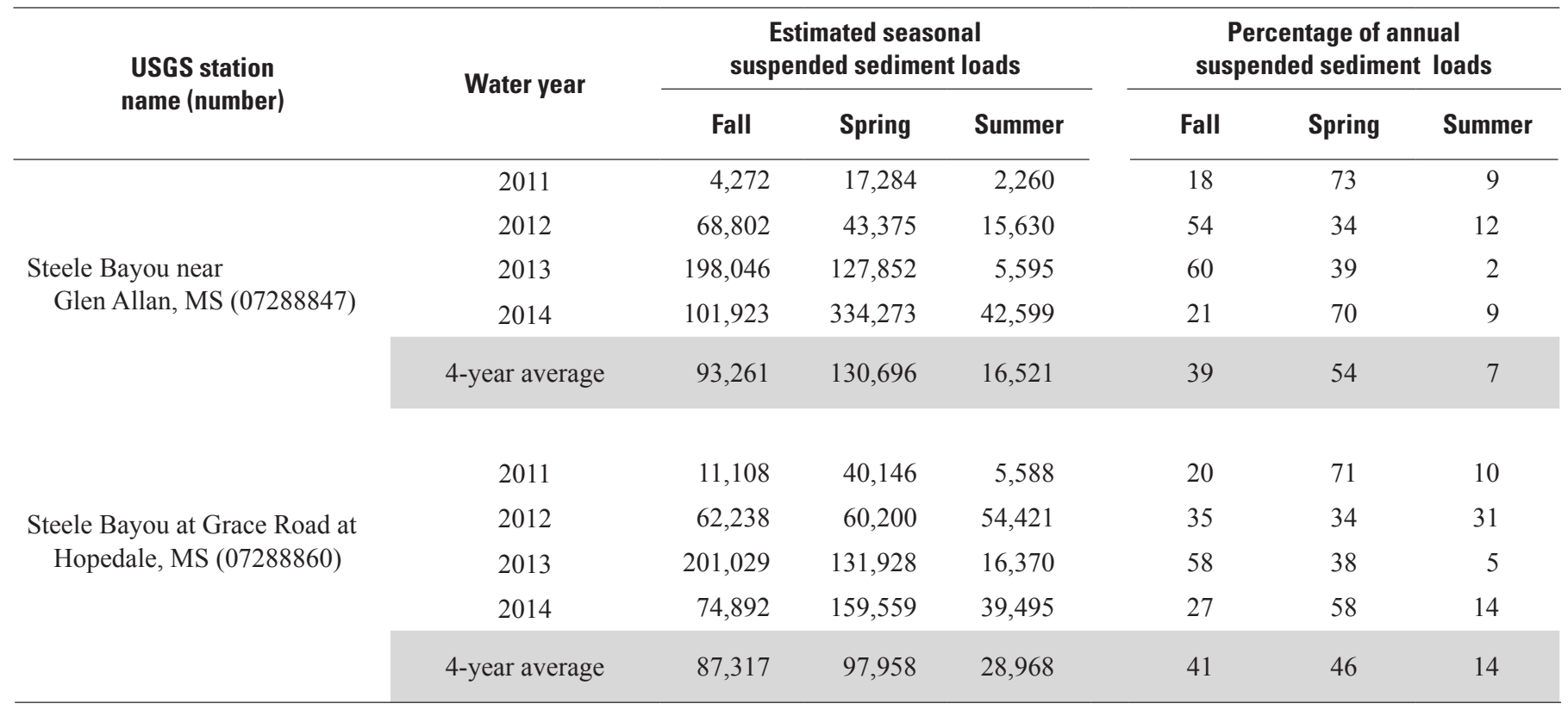

Table 14. Estimated annual total nitrogen loads, average annual streamflows, and flow-weighted mean total nitrogen concentrations at water-quality stations in the Steele Bayou Basin, Mississippi, October 2010 through September 2014.

[USGS, U.S. Geological Survey; $\mathrm{ft}^{3} / \mathrm{s}$, cubic foot per second; t/yr, metric ton per year; mg/L, milligrams per liter; MS, Mississippi]

\begin{tabular}{|c|c|c|c|c|}
\hline $\begin{array}{l}\text { USGS station } \\
\text { name (number) }\end{array}$ & Water year & $\begin{array}{l}\text { Estimated annual mean } \\
\text { total nitrogen load }(t / y r)\end{array}$ & $\begin{array}{c}\text { Annual mean } \\
\text { streamflow }\left(\mathrm{ft}^{3} / \mathrm{s}\right)\end{array}$ & $\begin{array}{c}\text { Estimated flow-weighted } \\
\text { mean total nitrogen con- } \\
\text { centration (mg/L) }\end{array}$ \\
\hline \multirow{4}{*}{$\begin{array}{l}\text { Steele Bayou near } \\
\text { Glen Allan, MS (07288847) }\end{array}$} & 2011 & 235 & 112 & 2.10 \\
\hline & 2012 & 756 & 331 & 2.28 \\
\hline & 2013 & 1,325 & 568 & 2.33 \\
\hline & 2014 & 1,166 & 502 & 2.32 \\
\hline \multirow{4}{*}{$\begin{array}{c}\text { Steele Bayou at Grace Road at } \\
\text { Hopedale, MS (07288860) }\end{array}$} & 2011 & 359 & 155 & 2.31 \\
\hline & 2012 & 749 & 407 & 1.84 \\
\hline & 2013 & 1,681 & 763 & 2.20 \\
\hline & 2014 & 1,155 & 607 & 1.90 \\
\hline
\end{tabular}


Table 15. Estimated annual total phosphorus loads, average annual streamflows, and flow-weighted mean total phosphorus concentrations at water-quality stations in the Steele Bayou Basin, Mississippi, October 2010 through September 2014.

[USGS, U.S. Geological Survey; ft³/s, cubic foot per second; t/yr, metric ton per year; mg/L, milligrams per liter; MS, Mississippi]

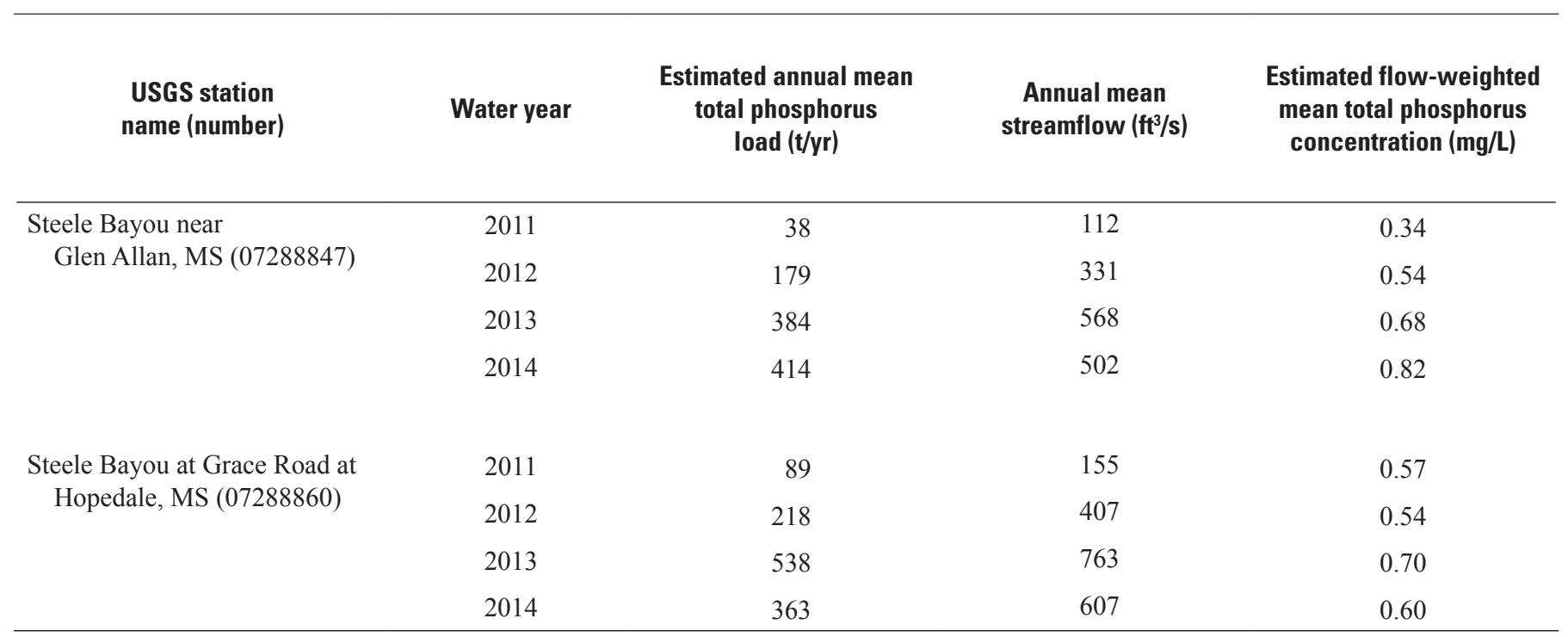

Table 16. Estimated annual suspended sediment loads, average annual streamflows, and flow-weighted mean sediment concentrations at water-quality stations in the Steele Bayou Basin, Mississippi, October 2010 through September 2014.

[USGS, U.S. Geological Survey; $\mathrm{ft}^{3} / \mathrm{s}$, cubic foot per second; t/yr, metric ton per year; mg/L, milligrams per liter; MS, Mississippi]

\begin{tabular}{|c|c|c|c|c|}
\hline $\begin{array}{l}\text { USGS station } \\
\text { name (number) }\end{array}$ & Water year & $\begin{array}{l}\text { Estimated annual mean } \\
\text { suspended sediment } \\
\text { load (t/yr) }\end{array}$ & $\begin{array}{c}\text { Annual mean } \\
\text { streamflow }\left(\mathrm{ft}^{3} / \mathrm{s}\right)\end{array}$ & $\begin{array}{l}\text { Estimated flow-weighted } \\
\text { mean suspended sediment } \\
\text { concentration (mg/L) }\end{array}$ \\
\hline \multirow{3}{*}{$\begin{array}{l}\text { Steele Bayou near } \\
\text { Glen Allan, MS (07288847) }\end{array}$} & 2011 & 23,816 & 112 & 212 \\
\hline & 2012 & 127,807 & 331 & 386 \\
\hline & 2014 & 478,795 & 502 & 953 \\
\hline \multirow{2}{*}{$\begin{array}{c}\text { Steele Bayou at Grace Road at } \\
\text { Hopedale, MS (07288860) }\end{array}$} & 2011 & 56,842 & 155 & 366 \\
\hline & 2012 & 176,859 & 407 & 434 \\
\hline
\end{tabular}


The highest and lowest annual FWM concentrations of total nitrogen, total phosphorus, and suspended sediment correspond to the years having the highest and lowest annual mean streamflow and largest and smallest total load at both stations. Estimated annual FWM concentrations of total nitrogen and total phosphorus were substantially larger than the endpoints specified as part of the TMDL for total nitrogen and total phosphorus of large rivers in the Delta $(1.05 \mathrm{mg} / \mathrm{L}$, total nitrogen; $0.16 \mathrm{mg} / \mathrm{L}$, total phosphorus) (Mississippi Department of Environmental Quality, 2008). Temporal patterns in FWM concentrations of nitrate plus nitrite and orthophosphate were similar to those observed for total nitrogen and phosphorus, respectively.

\section{Comparison of Nitrogen and Phosphorus Concentrations, Loads, and Yields to Historical Data, Other Agricultural Basins, and SPARROW Model Estimates}

The concentrations and loads and yields presented in this report are put into context by comparing these values to the limited historical nutrient concentrations collected in the Steele Bayou Basin, concentrations and loads from other agriculturally dominated basins, and estimated loads from

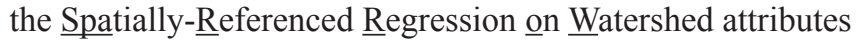
(SPARROW) model. These data therefore provide a baseline of information that may be used to document change over time, as well as link any observed improvements to landmanagement activities and practices, should data collection continue at these locations.

\section{Historical Nutrient Concentrations}

A study conducted in 1990 by Slack and Grantham (1991) documented monthly total nitrogen and phosphorus concentrations from 58 stations located throughout the upper Yazoo and Steele Bayou Basins. Sampling frequency among the 58 stations ranged from one sample per year to one sample per month. Flow conditions at the time of sampling were not recorded and presumably varied across the flow regime. Nutrient concentrations at the 58 stations in 1990 ranged between 0.36 and $14.4 \mathrm{mg} / \mathrm{L}$ (median of $1.73 \mathrm{mg} / \mathrm{L}$ ) for total nitrogen and between 0.07 and $1.8 \mathrm{mg} / \mathrm{L}$ (median of $0.32 \mathrm{mg} / \mathrm{L}$ ) for total phosphorus. Nutrients were sampled monthly at Steele Bayou near Glen Allan as part of the 1990 study; total nitrogen concentrations ranged from 1.6 to $3.9 \mathrm{mg} / \mathrm{L}$, with a median concentration of $2.1 \mathrm{mg} / \mathrm{L}$, and total phosphorus concentrations ranged from 0.2 to $0.44 \mathrm{mg} / \mathrm{L}$, with a median concentration of $0.35 \mathrm{mg} / \mathrm{L}$ (Slack and Grantham, 1991). The nutrient concentrations in 1990 at Steele Bayou near Glen Allan are higher than the median baseflow nutrient concentrations and lower than the median runoff nutrient concentrations observed in water years 2011-14 and reported in this study (table 2).

\section{Other Agricultural Basins}

To place the estimated loads and yields for water years 2011-14 at the two Steele Bayou stations in context, these estimates were compared to published load and yield estimates for nutrients and sediment at 20 agriculturally dominated basins in the southeastern and central United States (table 17). Drainage areas of the basins used for comparison ranged from 136 to $69,285 \mathrm{~km}^{2}$. All basins used for comparison were dominated by agricultural land use, which composed at least 75 percent of the total land use in each case. Many differences exist between the Steele Bayou Basin and the other basins presented in table 17, such as basin geology, soil type, climate, crop type, irrigation methods, fertilizer usage, and tile drainage. The Bogue Phalia Basin is located in the Delta and is similar to Steele Bayou Basin in terms of drainage area and land use, which is primarily agricultural. Estimated mean annual loads of total nitrogen from Steele Bayou are slightly smaller than, but relatively similar to, published loads from Bogue Phalia. Estimated mean annual yields of total nitrogen from Steele Bayou are generally larger than the yields reported at basins in Oklahoma, Arkansas, and Alabama but smaller than yields from basins located in States that are more intensively farmed, such as Iowa and Illinois (table 17). Mean annual nitrate plus nitrite yields at the two Steele Bayou stations, Bogue Phalia, and Yazoo River below Steele Bayou are smaller than the nitrate plus nitrite yields for all the other basins whose data were compiled. Mean annual phosphorus yields for both Steele Bayou stations are generally larger than most of the other compiled phosphorus yields. This is consistent with findings from data in other watersheds in this region (Kleiss and others, 2000; Runner and others, 2002). Total phosphorus concentrations often are related to sediment concentrations. Rivers in the Delta carry a substantial load of sediment, a large percentage of which is fine material (less than $0.63 \mu \mathrm{m}$ in diameter), to which phosphorus can adsorb (Runner and others, 2002). High phosphorus concentrations in Delta rivers may be explained by the natural fertility of the Delta soils. As with phosphorus yields, mean annual suspended-sediment yields are generally larger than most other yields from other agriculturally dominated basins. Nationally, suspended-sediment yield at the Steele Bayou near Glen Allen station is exceeded only by that at the Nishnabotna River above Hamburg, IA station. The suspended-sediment yield at Steele Bayou at Hopedale falls within the middle of the range of the compiled suspended-sediment yields (table 17). 
Table 17. Estimated annual total nitrogen, nitrite plus nitrate, total phosphorus and suspended sediment loads, from other published agricultural dominated basins and from water-quality stations in the Steele Bayou Basin, Mississippi, October 2010 through September 2014.

[USGS, U.S. Geological Survey; km², square kilometer; t/yr, metric ton per year; t/yr/km², metric ton per year per square kilometer; MS, Mississippi; OK, Oklahoma; AR, Arkansas; AL, Alabama; KY, Kentucky; IA, Iowa; IL, Illinois; OH, Ohio; — data not available]

\begin{tabular}{|c|c|c|c|c|c|c|c|c|c|}
\hline USGS station name & $\begin{array}{l}\text { Drainage } \\
\text { area }\left(\mathrm{km}^{2}\right)\end{array}$ & $\begin{array}{c}\text { Annual } \\
\text { nitrogen load } \\
\text { (t/yr) }\end{array}$ & $\begin{array}{c}\text { Annual nitrite } \\
+ \text { nitrate load } \\
\text { (t/yr) }\end{array}$ & $\begin{array}{c}\text { Annual } \\
\text { phosphorus } \\
\text { load (t/yr) }\end{array}$ & $\begin{array}{c}\text { Annual } \\
\text { suspended } \\
\text { sediment } \\
\text { load (t/yr) }\end{array}$ & $\begin{array}{c}\text { Annual nitro- } \\
\text { gen yield (t/ } \\
\text { yr/km²) }\end{array}$ & $\begin{array}{c}\text { Annual nitrite } \\
\text { + nitrate yield } \\
\text { (t/yr/km²) }\end{array}$ & $\begin{array}{c}\text { Annual phos- } \\
\text { phorus yield } \\
\text { (t/yr/km²) }\end{array}$ & $\begin{array}{c}\text { Annual } \\
\text { suspended } \\
\text { sediment yield } \\
\left(\mathrm{t} / \mathrm{yr} / \mathbf{k m}^{2}\right)\end{array}$ \\
\hline Steele Bayou near Glen Allan, MS & 837 & 871 & 363 & 254 & 240,478 & 1.041 & 0.434 & 0.304 & 287.459 \\
\hline $\begin{array}{l}\text { Steele Bayou at Grace Road near } \\
\text { Hopedale, MS }\end{array}$ & 1,031 & 986 & 283 & 302 & 214,243 & 0.957 & 0.275 & 0.293 & 207.839 \\
\hline Bogue Phalia near Leland, $\mathrm{MS}^{1}$ & 1,254 & 1,860 & 481 & 345 & 258,000 & 1.483 & 0.384 & 0.275 & 205.7 \\
\hline Yazoo River below Steele Bayou, $\mathrm{MS}^{1}$ & 34,589 & 22,800 & 6,420 & 4,670 & - & 0.659 & 0.186 & 0.135 & - \\
\hline Baron Fork at Eldon, $\mathrm{OK}^{1}$ & 795 & 782 & 566 & 70 & - & 0.984 & 0.712 & 0.088 & - \\
\hline Black Fork at Hodgen, $\mathrm{OK}^{1}$ & 464 & 196 & - & - & 8,790 & 0.422 & - & - & 18.9 \\
\hline James Fork near Hackett, $\mathrm{AR}^{1}$ & 381 & 269 & - & 33 & 18,600 & 0.706 & - & 0.087 & 48.8 \\
\hline Bogue Chitto Creek near Memphis, $\mathrm{AL}^{2}$ & 136 & 64 & 142 & 14 & 15,700 & 0.470 & 1.042 & 0.103 & 115.2 \\
\hline Poteau River near Loving, $\mathrm{OK}^{3}$ & 694 & 405 & - & 85 & 39,128 & 0.583 & - & 0.122 & 56.4 \\
\hline Poteau River near Heavener, $\mathrm{OK}^{3}$ & 1,334 & 752 & - & 157 & 123,600 & 0.564 & - & 0.118 & 92.7 \\
\hline Fourche Maline near Leflore, $\mathrm{OK}^{3}$ & 692 & 291 & - & 49 & 44,589 & 0.421 & - & 0.071 & 64.5 \\
\hline $\begin{array}{l}\text { North Fork Little River at Gary Lane } \\
\text { Bridge near Hopkinsville, } \mathrm{KY}^{4}\end{array}$ & 150 & - & 204 & 49 & 13,608 & - & 1.358 & 0.323 & 90.6 \\
\hline Sinking Fork near Hopkinsville, KY & 277 & 544 & - & 52 & - & 1.963 & - & 0.187 & - \\
\hline Little Sioux River at Turin, IA $^{5}$ & 9,132 & 12,400 & 7,850 & 1,430 & $2,060,000$ & 1.358 & 0.860 & 0.157 & 225.6 \\
\hline
\end{tabular}


Table 17. Estimated annual total nitrogen, nitrite plus nitrate, total phosphorus and suspended sediment loads, from other published agricultural dominated basins and from water-quality stations in the Steele Bayou Basin, Mississippi, October 2010 through September 2014.—Continued

[USGS, U.S. Geological Survey; km², square kilometer; t/yr, metric ton per year; t/yr/km², metric ton per year per square kilometer; MS, Mississippi; OK, Oklahoma; AR, Arkansas; AL, Alabama; KY, Kentucky; IA, Iowa; IL, Illinois; OH, Ohio; — data not available]

\begin{tabular}{|c|c|c|c|c|c|c|c|c|c|}
\hline USGS station name & $\begin{array}{c}\text { Drainage } \\
\text { area }\left(\mathbf{k m}^{2}\right)\end{array}$ & $\begin{array}{c}\text { Annual } \\
\text { nitrogen load } \\
\text { (t/yr) }\end{array}$ & $\begin{array}{c}\text { Annual nitrite } \\
+ \text { nitrate load } \\
\text { (t/yr) }\end{array}$ & $\begin{array}{c}\text { Annual } \\
\text { phosphorus } \\
\text { load (t/yr) }\end{array}$ & $\begin{array}{c}\text { Annual } \\
\text { suspended } \\
\text { sediment } \\
\text { load (t/yr) }\end{array}$ & $\begin{array}{c}\text { Annual nitro- } \\
\text { gen yield (t/ } \\
\text { yr/km²) }\end{array}$ & $\begin{array}{c}\text { Annual nitrite } \\
+ \text { nitrate yield } \\
\left(\mathrm{t} / \mathrm{yr} / \mathrm{km}^{2}\right)\end{array}$ & $\begin{array}{c}\text { Annual phos- } \\
\text { phorus yield } \\
\left(t / \mathbf{y r} / \mathbf{k m}^{2}\right)\end{array}$ & $\begin{array}{c}\text { Annual } \\
\text { suspended } \\
\text { sediment yield } \\
\left(\mathrm{t} / \mathrm{yr} / \mathbf{k m}^{2}\right)\end{array}$ \\
\hline Boyer River at Logan, $\mathrm{IA}^{5}$ & 2,256 & 3,630 & 2,660 & 406 & 587,000 & 1.609 & 1.179 & 0.180 & 260.2 \\
\hline Nishnabotna River above Hamburg, IA $^{5}$ & 7,267 & 12,500 & 10,200 & 2,020 & $3,620,000$ & 1.720 & 1.404 & 0.278 & 498.1 \\
\hline Skunk River at Augusta, IA $^{5}$ & 11,168 & 22,000 & 16,100 & 1,360 & $1,380,000$ & 1.970 & 1.442 & 0.122 & 123.6 \\
\hline Wapsipinicon River near De Witt, IA ${ }^{5}$ & 6,050 & 19,300 & 17,200 & 649 & 405,000 & 3.190 & 2.843 & 0.107 & 66.9 \\
\hline Maquoketa River near Spragueville, IA $^{5}$ & 4,022 & 12,500 & 9,750 & 675 & 661,000 & 3.108 & 2.424 & 0.168 & 164.3 \\
\hline Turkey River at Garber, IA $^{5}$ & 4,002 & 14,800 & 10,200 & 1,500 & $1,350,000$ & 3.699 & 2.549 & 0.375 & 337.4 \\
\hline Illinois River at Valley City, $\mathrm{IL}^{6}$ & 69,285 & 137,000 & 119,000 & 8,580 & $3,260,000$ & 1.977 & 1.718 & 0.124 & 47.1 \\
\hline Auglaize River near Fort Jennings, $\mathrm{OH}^{6}$ & 860 & 2,850 & 3,600 & 82 & 32,500 & 3.314 & 4.186 & 0.095 & 37.8 \\
\hline \multicolumn{10}{|l|}{ SPARROW model results ${ }^{7}$} \\
\hline Steele Bayou & 1,548 & 1,252 & - & 146 & - & 0.809 & - & 0.094 & - \\
\hline
\end{tabular}

${ }^{1}$ Rebich and Demcheck, (2007).

${ }^{2}$ McPherson and others, (2003).

${ }^{3}$ Buck, (2014).

${ }^{4}$ Crain, (2006).

${ }^{5}$ Garrett, (2012).

${ }^{6}$ Lorenz and others, (2009).

${ }^{7}$ Rebich and others, (2011). 


\section{SPARROW Model Estimates}

Results from the Steele Bayou Basin were also compared to SPARROW modeling results by Rebich and others (2011), and are provided in table 17. SPARROW is a hybrid, statistical, geographic information system (GIS), and process-based model that links monitored water-quality data to attributes of watersheds, such as contaminant sources, transport and delivery rates to streams, and instream processing. Similar to other models, SPARROW models are calibrated with load data at monitored locations to estimate loads at unmonitored locations. Estimates of total nitrogen and total phosphorus from SPARROW models by Rebich and others (2011) represent long-term mean annual loads. The mean annual total nitrogen loads at both Steele Bayou stations are similar to the estimate produced by SPARROW (table 17). However, estimates of mean annual phosphorus loads at both Steele Bayou stations were up to 2 times larger than the estimate for the Steele Bayou by the SPARROW model. Furthermore, every annual total phosphorus load estimated for water years 2012-14 at the two Steele Bayou stations in this report (table 6) exceeded the SPARROWestimated load. Differences between the phosphorus loads presented in the current study and those estimated by SPARROW may be a consequence of the few available calibration sites in the SPARROW total phosphorus model in the Delta region, which may result in greater standard error for SPARROW load estimates than if more calibration sites were available and used. Confidence intervals for SPARROW phosphorus load estimates ranged from 26 to 461 metric tons (R.A. Rebich, U.S. Geological Survey, written commun., 2016) which overlap phosphorus loads and associated confidence intervals presented in this report.

\section{Summary and Conclusions}

The U.S. Geological Survey, in cooperation with the U.S. Army Corps of Engineers-Vicksburg District, characterized streamflow, water-quality, and sediment data between October 2010 and September 2014 in the Steele Bayou Basin. Rivers in this predominately agricultural region of Mississippi typically have large annual inputs of nutrients and sediment from point and nonpoint sources, a large portion of which is often attributed to runoff from farm fields. Elevated concentrations of nutrients and sediment have been document in the Steele Bayou, and since the early 1990s, various conservation practices have been implemented in the Steele Bayou Basin in an effort to reduce the amount of nutrients and sediments in the Steele Bayou and its tributaries. Data were characterized for two streamflow-gaging stations along the Steele Bayou: Steele Bayou near Glen Allan, MS (upstream) and Steele Bayou at Grace Road at Hopedale, MS (downstream). This characterization documented the status of water quality in the basin following over two decades of ongoing implementation of conservation practices.

In general, water quality was similar at the two gaging stations. Concentrations of total nitrogen, nitrate plus nitrite, total phosphorus, orthophosphate, and suspended sediment were slightly higher at the upstream station than at the downstream station, although the differences were typically not statistically significant. However, concentrations of most constituents were significantly higher during runoff than during baseflow at both stations.

Annual loads generally were similar between stations, although they were consistently larger at the upstream station. The majority of nutrient and sediment loading occurred during the spring (February through May) at both stations and for most constituents, with about 50 percent of the total annual load contributed during this season. The exception was orthophosphate, with about 40 percent of its annual load contributed during the spring. Large loads of nutrient and sediment were also contributed during the fall and ranged from 35 to 45 percent of the total annual load. Comparison of the nutrient and sediment loads and yields for the Steele Bayou Basin to other agricultural basins in the southeastern and central United States indicated that the Steele Bayou Basin had total nitrogen, phosphorus, and suspended-sediment yields comparable to those of the other basins. Nitrate plus nitrite yields were smaller, however, in the Mississippi River alluvial plain, including the Steele Bayou Basin, than in the other agricultural basins.

Although it was not possible to assess the direct effect of conservation practices on water quality in the Steele Bayou using the data currently available, it was possible to characterize streamflow, water quality, and sediment in a specific watershed that experienced widespread implementation of conservation practices. This characterization may serve as a benchmark for addressing future changes in the Steele Bayou or other rivers in the Mississippi River alluvial plain.

\section{Acknowledgments}

The authors would like to thank many people for their contributions to the data collection and analysis presented in this report. Special thanks go to Rheannon Hart for generating maps used in this report and to Greg Johnson for running the load models. The authors also appreciate the peer reviews by Angela Crain and Scott Mize. The authors also thank Richard Rebich and Bill Wolfe for their guidance and reviews provided throughout the duration of the entire project. 


\section{References Cited}

Akaike, H., 1973, Information theory and an extension of the maximum likelihood principle, in Petrov, B.N., and Csaki, F., eds., 2nd International Symposium on Information Theory: Budapest, Akademia Kiado, p. 267-281.

Alexander, R.B., Smith, R.A., Schwarz, G.E., Boyer, E.W., Nolan, J.V., and Brakebill, J.W., 2008, Differences in phosphorus and nitrogen delivery to the Gulf of Mexico from the Mississippi River Basin: Environmental Science and Technology, v. 42, p. 822-830.

Ashby, S.L., Sturgis, T.C., Price, C.B., Brannon, J.M., and Pennington, J.C., 1991, Water quality studies in the upper watershed of Steele Bayou, Mississippi: Vicksburg, Miss, U.S. Army Engineer Waterways Experiment Station, Miscellaneous Paper EL-91-23.

Buchanan, T.J., and Somers, W.P., 1969, Discharge measurements at gaging stations: U.S. Geological Survey Techniques of Water-Resources Investigations, book 3, chap. A8, 65 p.

Buck, S.D., 2014, Concentrations, loads, and yields of total phosphorus, total nitrogen, and suspended sediment and bacteria concentrations in the Wister Lake Basin, Oklahoma and Arkansas, 2011-13: U.S. Geological Survey Scientific Investigations Report 2014-5170, 39 p., accessed September 2015 at http://dx.doi.org/10.3133/sir20145170.

Cohn, T.A., 2005, Estimating contaminant loads in rivers: An application of adjusted maximum likelihood to type 1 censored data: Water Resources Research, v. 41, W07003, accessed September 2015 at http://dx.doi. org/10.1029/2004WR003833.

Crain, A.S., 2006, Concentrations and estimated loads and yields of nutrients and suspended sediment in the Little River Basin, Kentucky, 2003-04: U.S. Geological Survey Scientific Investigations Report 2006-5204, 31 p.

Fishman, M.J., ed., 1993, Methods of analysis by the U.S. Geological Survey National Water Quality LaboratoryDetermination of inorganic and organic constituents in water and fluvial sediments: U.S. Geological Survey Open-File Report 93-125, 217 p.Garrett, J.D., 2012, Concentrations, loads, and yields of select constituents from major tributaries of the Mississippi and Missouri Rivers in Iowa, water years 2004-2008: U.S. Geological Survey Scientific Investigations Report 2012-5240, 61 p.

Helsel, D.R., and Hirsch, R.M., 1992, Statistical methods in water resources: Amsterdam, Netherlands, Elsevier, 522 p.

Herbonne, B.A., and Vondracek, B., 2001, Effects of local land use on physical habitat, benthic macroinvertebrates, and fish in the Whitewater River, Minnesota, USA: Environmental Management, v. 28, p. 87-99.
Hurvitch, C.M., and Tsai, C.L., 1989, Regression and time series model selection in small samples: Biometrika, v. 76, no. 2, p. 297-307.

Kennedy, E.J., 1983, Computation of continuous records of streamflow: U.S. Geological Survey Techniques of WaterResources Investigations, book 3, chap. A13, 53 p.

Killgore, K.J., Hoover, J.J., Murphy, C.E., Parrish, K.D., Johnson, D.R., and Myers, K.F., 2008, Restoration of Delta streams: A case history and conceptual model: Vicksburg, Miss: U.S. Army Engineer Research and Development Center, EMRRP Technical Notes Collection, ERDC TN-EMRRP-ER-08.

Kleiss, B.A., Coupe, R.H., Gonthier, G.J., and Justus, B.G., 2000, Water quality in the Mississippi embayment, Mississippi, Louisiana, Arkansas, Missouri, Tennessee, and Kentucky, 1995-1998: U.S. Geological Survey Circular 1208, 36 p.

Lorenz, D.L., Robertson, D.M., Hall, D.W., and Saad, D.A., 2009, Trends in streamflow and nutrient and suspended-sediment concentrations and loads in the Upper Mississippi, Ohio, Red, and Great Lakes River Basins, 1975-2004: U.S. Geological Survey Scientific Investigations Report 2008-5213, $81 \mathrm{p}$.

Lorenz, D.L., Runkel, R.L., and De Cicco, L., 2013, rloadest: USGS water science R functions for LOAD ESTimation of constituents in rivers and streams, $v$ 0.4.1: Accessed June 20, 2015, at https://github.com/USGS-R/rloadest.

McPherson, A.K., Moreland, R.S., and Atkins, J.B., 2003, Occurrence and distribution of nutrients, suspended sediment, and pesticides in the Mobile River Basin, Alabama, Georgia, Mississippi, and Tennessee, 1999-2001: U.S. Geological Survey Water-Resources Investigations Report 03-4203, 101 p.

Mississippi Department of Environmental Quality, 2003, Sediment TMDL for Steele Bayou watershed including Main Canal, Granny Baker Bayou, Granicus Bayou, and Black Bayou: Mississippi Department of Environmental Quality, 25 p.

Mississippi Department of Environmental Quality, 2008, Total nitrogen and total phosphorus for selected large rivers in the Delta: Mississippi Department of Environmental Quality, $25 \mathrm{p}$.

Mississippi Department of Environmental Quality, 2009, Mississippi delta nutrient reduction strategiesImplementation draft: FTN Associates, Ltd., 52 p.

Nash, J.E., and Sutcliffe, J.V., 1970, River flow forecasting through conceptual models part I-A discussion of principles: Journal of Hydrology, v. 10, no. 3, p. 282-290. 
National Oceanic and Atmospheric Administration, 2016, Climate data online: National Oceanic and Atmospheric Administration Web site, accessed October 2015 at http:// www.ncdc.noaa.gov/cdo-web/.

Patton, C.J., and Kryskalla, J.R., 2003, Methods of analysis by the U.S. Geological Survey National Water Quality Laboratory-Evaluation of alkaline persulfate digestion as an alternative to Kjeldahl digestion for determination of total and dissolved nitrogen and phosphorus in water: U.S. Geological Survey Water-Resources Investigations Report 03-4174, 33 p.

Patton, C.J., and Truitt, E.P., 1992, Methods of analysis by the U.S. Geological Survey National Water Quality Laboratory-Determination of the total phosphorus by the Kjeldahl digestion method and an automated colorimetric finish that includes dialysis: U.S. Geological Survey OpenFile Report 92-146, 39 p.

Rantz, S.E., and others, 1982, Measurement and computation of streamflow: Volume 2. Computation of discharge: U.S. Geological Survey Water-Supply Paper 2175, 285 p.

Rebich, R.A., and Demcheck, D.K., 2007, Trends in nutrient and sediment concentrations and loads in major river basins of the south-central United States, 1993-2004: U.S. Geological Survey Scientific Investigations Report 20075090, 112 p.

Rebich, R.A., Houston, N.A., Mize, S.V., Pearson, D.K., Ging, P.B. and Hornig, C.E., 2011, Sources and delivery of nutrients to the northwestern Gulf of Mexico from streams in the south-central United States: Journal of the American Water Resources Association, v. 47, p. 1061-1086. http:// dx.doi.org/10.1111/j.1752-1688.2011.00583.x.

Robertson, D.M., Schwarz, G.E., Saad, D.A., and Alexander, R.B., 2009, Incorporating uncertainty into the ranking of SPARROW model nutrient yields from Mississippi/Atchafalaya River Basin watersheds: Journal of the American Water Resources Association v. 45, no. 2, p. 534-549.

Runkel, R.L., Crawford, C.G., and Cohn, T.A., 2004, Load estimator (LOADEST): A FORTRAN program for estimating constituent loads in streams and rivers: U.S. Geological Survey Techniques and Methods, book 4, chap. A5, 69 p.
Runner, M.S., Turnipseed, D.P., and Coupe, R.H., 2002, Streamflow and nutrient data for the Yazoo River below Steele Bayou near Long Lake, Mississippi, 1996-2000: U.S. Geological Survey Water-Resources Investigations Report, 35 p.

Slack, L.J., and Grantham, P.E., 1991, Quality of water in the upper Yazoo River and Steele Bayou Basins, northwestern Mississippi, March 1990 through February 1991: U.S. Geological Survey Open-File Report, 46 p.

Storm, D.E., White, Michael, Smolen, M.D., and Zang, Hailin, 2001, Modeling total phosphorus loading for the Lake Eucha Basin: Stillwater, Okla., Oklahoma State University, Biosystems and Agriculture Engineering Department, 14 p.

Tortorelli, R.L., 2008, Nutrient concentrations, loads, and yields in the Eucha-Spavinaw Basin, Arkansas and Oklahoma, 2002-2006: U.S. Geological Survey Scientific Investigations Report 2008-5174, 56 p.

U.S. Environmental Protection Agency, 1993, Determination of phosphorus by semi-automated colorimetry (revision 2.0), method 365.1 of Methods for the determination of inorganic substances in environmental samples: U.S. Environmental Protection Agency EPA/600/R-93/100, p. 365.1-1-365.1-17.

U.S. Geological Survey, 2016, National Water Information System-Web interface: Accessed September 28, 2016, at http://dx.doi.org/10.5066/F7P55KJN.

U.S. Geological Survey, variously dated, National field manual for the collection of water-quality data: U.S. Geological Survey Techniques of Water-Resources Investigations, book 9, chaps. A1-A10. [Also available online at http://pubs. water.usgs.gov/twri9A.]

Vecchia, Aldo, 2003, Relation between climate variability and stream water quality in the continental United States: Hydrological Science and Technology, v. 19, no. 1, p. 77-98.

Wood, P.J., and Armitage, P.D., 1997, Biological effects of fine sediment in the lotic environment: Environmental Management, v. 21, no. 2, p. 203-217. 
Publishing support provided by Lafayette Publishing Service Center

For more information about this product, contact: Director Lower Mississippi Gulf Water Science Center U.S. Geological Survey 308 Airport Rd. Jackson MS 39208

Or visit our website at: https://www.usgs.gov/centers/lmg-water 


\section{$\frac{\mathbb{2}}{3}$}

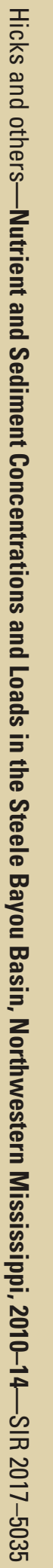

